Article

\title{
Design and Comparative Techno-Economic Analysis of Two Solar Polygeneration Systems Applied for Electricity, Cooling and Fresh Water Production
}

\author{
Ighball Baniasad Askari ${ }^{1}\left(\mathbb{D}\right.$, Francesco Calise $^{2, *(\mathbb{D}}$ and Maria Vicidomini ${ }^{2}$ \\ 1 Department of Mechanical Engineering, Faculty of Engineering, University of Zabol, P.O. Box 98615-538, \\ Zabol, Iran; eghball.baniasad@uoz.ac.ir \\ 2 Department of Industrial Engineering, University of Naples Federico II, P. le Tecchio 80, 80125 Naples, Italy; \\ maria.vicidomini@unina.it \\ * Correspondence: frcalise@unina.it; Tel.: +39-08-1768-2301
}

Received: 7 October 2019; Accepted: 13 November 2019; Published: 19 November 2019

\begin{abstract}
Two solar polygeneration systems were investigated for electricity, cooling and fresh water production. In the first scenario $\left(\mathrm{LF}_{\mathrm{PS}}\right)$, the linear Fresnel (LF) solar field was used as thermal source of the Organic Rankine Cycle (ORC), absorption chiller (ACH) and multi-effect desalination (MED) unit. In the second scenario ( $\mathrm{PV}$ PS), photovoltaic $(\mathrm{PV})$ panels were considered as the electricity source to supply the electricity load that is required for lighting, electrical devices, compression chiller $(\mathrm{CCH})$ and reverse osmosis $(\mathrm{RO})$ units. A techno-economic comparison was made between two scenarios based on the land use factor (F), capacity utilization factor (CUF), payback period, levelized cost of electricity (LCE), levelized cost of cooling energy (LCC) and levelized cost of water (LCW). The calculations were conducted for four different locations in order to determine the effect of solar radiation level on the LCE, LCC and LCW of systems in both scenarios. The results showed that the LCE and LCW of PVPS is lower than that of LFPS and the LCC of LFPS is lower than that of PVPS. Also, the payback period of $L F_{P S}$ and $P V_{P S}$ systems are obtained as 13.97 years and 13.54 years, respectively, if no incentive is considered for the electricity sale.
\end{abstract}

Keywords: linear Fresnel; Organic Rankine Cycle; photovoltaic; chiller; desalination; natural gas fuel

\section{Introduction}

One of the most promising, endless and free renewable energy resources is solar energy. The worldwide renewable energy capacity has grown by $85 \%$ during the last decade [1]. The solar electricity generation can be classified in two main technologies; (a) photovoltaic (PV) technology and (b) concentrated solar power (CSP) technology. The former converts the global horizontal irradiance (GHI) and the latter converts the direct and global solar radiations (known as direct normal irradiance (DNI)). The global installed capacity of the CSP and PV technologies have been predicted by the International Energy Agency (IEA) to reach $261 \mathrm{GW}$ and $1761 \mathrm{GW}$, respectively, by 2030 [2,3]. Although the annual growth rate of photovoltaic (PV) solar energy has shown to be $40 \%$ during the last decade, it only represented $0.2 \%$ of the total global electricity production until 2014 [4]. Humanity will encounter two main challenges in the coming years: (a) energy and water scarcity, which is happening because of the growth in population, industry, agriculture development and tourism, and (b) reducing the global emissions caused by fossil fuel consumption. During the past decades, fossil fuel availability was considered one of the main issues. However, the problem of water availability is becoming more and more critical, even more so than energy. It is also worth noting that energy and water availability issues are often strictly connected. In many cases, such as in arid or coastal regions, fresh water is 
produced from seawater using thermal or electrical energy. The Middle East (ME) is rich in fossil fuel and solar energy resources, however, this region suffers from water scarcity and because the low fuel cost, high fossil fuel consumption and consequently the annual carbon dioxide $\left(\mathrm{CO}_{2}\right)$ emissions in the ME countries are high. For instance, Iran and Saudi Arabia, with total annual $\mathrm{CO}_{2}$ emissions of 536.4 million tones and 527.2 million tonnes, are respectively the 8th and 10th ranked countries in $\mathrm{CO}_{2}$ emission production across the world, according to the IEA report in 2016 [5]. Therefore, the applications of solar energy would be useful to reduce fuel consumption of the ME countries; especially for Iran that has recently decided to decrease its fossil fuel subsidies [6]. Only fully renewable or nearly fully renewable-based systems can satisfy the goals in terms of low fossil fuel consumption and low environmental impact. However, this goal would not be achieved within the next decade due to the present fuel-based energy costs [7]. In conventional applications, electricity is supplied by national electricity grids, heat is generated by boilers or heat pumps and cooling requirements are supplied by electric chillers [8]. Several alternatives can be considered to decrease the fossil fuel consumption and the environmental pollution, such as renewable-based distributed generation, district heating and cooling and polygeneration systems [9].

The present paper deals with design and comparative feasibility analysis of two renewable polygeneration systems powered by solar energy to produce electricity, fresh water and space cooling for a community located on the southern coast of Iran in the Persian Gulf. Both systems were supposed to be connected to district electricity, heating and cooling networks. The first system includes the Linear Fresnel solar field (LF), Organic Rankine Cycle (ORC), a double effect $\mathrm{LiBr} / \mathrm{H}_{2} \mathrm{O}$ absorption chiller $(\mathrm{ACH})$ and a multi-effect/thermal vapor compression desalination (MED/TVC) system. In the second system, a solar photovoltaic (PV) plant powers the required electricity of the building, a conventional compression chiller $(\mathrm{CCH})$ and a reverse osmosis $(\mathrm{RO})$ desalination unit. No thermal energy storage (TES) system is included in either of the polygeneration systems and the thermal energy shortage of the first scenario is met by an auxiliary natural gas boiler (NGB). Several research works in the literature have investigated multi-generation systems by exploitation of single or poly-renewable sources. Also, extensive literature has been dedicated to dual purpose and multi-generation systems powered either by high temperature solar thermal energy from Solar Rankine Cycles (SRCs) or medium temperature Solar Organic Rankine cycles (SORCs) in order to investigate their performance and the unit costs of the products. ORC technology is a widely investigated and commercialized technology which is suitable for the electricity generation from low or medium thermal sources. A significant attention has been paid to ORC technology in order to investigate their potential in various applications. Table 1 lists the previous studies that have been conducted on different energy generation or fresh water production system.

Table 1. Specifications of different hybrid electricity, heating, cooling and fresh water systems that have been investigated in the previous studies.

\begin{tabular}{|c|c|c|c|c|}
\hline Ref. & Technology/Temperature & Modelling/Review & Results & Applications \\
\hline [10] & PVT and CPVT & Review & Please refer to paper & $\begin{array}{l}\text { Electricity and } \\
\text { heating }\end{array}$ \\
\hline [11] & $\begin{array}{c}\mathrm{PVT} / \mathrm{ACH} / \mathrm{Bat} / \mathrm{NGB} \\
\left(50-60^{\circ} \mathrm{C}\right)\end{array}$ & $\begin{array}{l}\text { Energy, economic, } \\
\text { environmental }\end{array}$ & $\begin{array}{c}\text { System payback time: } \\
10.6-11.3 \text { years }\end{array}$ & $\begin{array}{c}\text { Electricity, space } \\
\text { heating and cooling }\end{array}$ \\
\hline$[12]$ & $\begin{array}{l}\text { PTC/ORC and LF/ORC } \\
\left(\mathrm{Up} \text { to } 400^{\circ} \mathrm{C}\right)\end{array}$ & $\begin{array}{l}\text { Techno-economic } \\
\text { assessment }\end{array}$ & $\begin{array}{c}\text { PTC/ORC: } 0.344-0.476 \$ / \mathrm{kWh}, \\
\text { LF/ORC: } 0.353-0.488 \$ / \mathrm{kWh}\end{array}$ & Electricity \\
\hline [13] & $\begin{array}{c}\text { CPVT/Biomass/ACH/MED } \\
\left(90^{\circ} \mathrm{C}\right)\end{array}$ & $\begin{array}{l}\text { Exergetic and } \\
\text { exergo-economic } \\
\text { analysis }\end{array}$ & $\begin{array}{c}\text { Electricity: } \\
0.042 € / \mathrm{kWh}-0.268 € / \mathrm{kWh} \\
\text { Heating: } 0.007 € / \mathrm{kWh}_{\mathrm{t}^{-}} \\
0.077 € / \mathrm{kWh} \mathrm{t} \text { Cooling: } \\
0.008 € / \mathrm{kWh}_{\mathrm{t}^{-}} \\
0.086 € / \mathrm{kWh}_{\mathrm{t}} \\
\text { Fresh water: } 1.7 € / \mathrm{m}^{3}- \\
8 € / \mathrm{m}^{3}\end{array}$ & $\begin{array}{l}\text { Electricity, space } \\
\text { heating, cooling } \\
\text { and fresh water }\end{array}$ \\
\hline
\end{tabular}


Table 1. Cont.

\begin{tabular}{|c|c|c|c|c|}
\hline Ref. & Technology/Temperature & Modelling/Review & Results & Applications \\
\hline [14] & $\begin{array}{l}\text { PTC/Geothermal/ACH/MED } \\
\left(160-200^{\circ} \mathrm{C}\right)\end{array}$ & $\begin{array}{l}\text { Exergo-economic } \\
\text { analysis }\end{array}$ & $\begin{array}{c}\text { Electricity: } 0.1475-0.1722 \\
€ / \mathrm{kWh} \text {, Cooling: } \\
0.5695-0.6023 € / \mathrm{kWh} \\
\text { Fresh water: } \\
0.431-0.458 € / \mathrm{m}^{3} .\end{array}$ & $\begin{array}{l}\text { Electricity, space } \\
\text { heating, cooling } \\
\text { and fresh water }\end{array}$ \\
\hline [15] & $\begin{array}{c}\text { PTC/ORC } \\
\left(235-300^{\circ} \mathrm{C}\right)\end{array}$ & $\begin{array}{l}\text { Energy and } \\
\text { economic }\end{array}$ & $\begin{array}{l}\text { ORC efficiency: } 19.57-25.36 \% \\
\text { System Payback time: } 9 \text { years }\end{array}$ & Electricity: $1 \mathrm{MW}$ \\
\hline [16] & $\begin{array}{l}\text { ETC/ORC } \\
\left(230^{\circ} \mathrm{C}\right)\end{array}$ & $\begin{array}{l}\text { Energy and } \\
\text { economic }\end{array}$ & $\begin{array}{l}\text { ORC efficiency: } 10 \% \text { System } \\
\text { Payback time: } 10 \text { years }\end{array}$ & Electricity: $6 \mathrm{~kW}$ \\
\hline [17] & $\begin{array}{c}\text { PTC/ORC } \\
\text { nanoparticles with thermal } \\
\text { oil }\left(300^{\circ} \mathrm{C}\right)\end{array}$ & Technical Model & $\begin{array}{c}\text { System efficiency }=20.11 \% \\
\text { and is improved by } 1.75 \% \\
\text { using the Nano fluid in the } \\
\text { ORC }\end{array}$ & $\begin{array}{l}\text { Electricity: } \\
167 \mathrm{~kW}\end{array}$ \\
\hline [18] & $\begin{array}{l}\text { Waste heat/PTC/ORC } \\
\left(150-300^{\circ} \mathrm{C}\right)\end{array}$ & Technical Model & $\begin{array}{c}\text { System efficiency from } \\
11.6-19.7 \%\end{array}$ & $\begin{array}{l}\text { Electricity: } \\
479-845 \mathrm{~kW}\end{array}$ \\
\hline [19] & $\begin{array}{c}\mathrm{EFPC}^{2} / \mathrm{ORC} \text { and } \mathrm{EFPC} / \mathrm{HP}^{3} \\
\left(80-170^{\circ} \mathrm{C}\right)\end{array}$ & $\begin{array}{l}\text { Energy and } \\
\text { economic }\end{array}$ & $\begin{array}{l}\text { System Payback: } \\
\text { EFPC/ORC: } 3.8 \text { years } \\
\text { EFPC/HP: } 3.1 \text { years }\end{array}$ & $\begin{array}{l}\text { Electricity and } \\
\text { heating }\end{array}$ \\
\hline [20] & $\begin{array}{l}\text { PTC/ACH Single effect } \\
\left(90^{\circ} \mathrm{C}\right)\end{array}$ & Technical modeling & ACH COP: $0.66-0.76$ & $\begin{array}{l}\text { Cooling: } \\
17.5 \mathrm{~kW}\end{array}$ \\
\hline [21] & $\begin{array}{l}\text { ACH (double effect parallel } \\
\left.\text { and series flows } \mathrm{LiBr} / \mathrm{H}_{2} \mathrm{O}\right) \\
\left(145-185^{\circ} \mathrm{C}\right)\end{array}$ & Technical modeling & $\begin{array}{l}\text { ACH COP: } \\
0.45-1.35\end{array}$ & $\begin{array}{c}\text { The effects of } \\
\text { generator } T \text { and } \dot{m} \\
\text { inlet vapor on COP }\end{array}$ \\
\hline [22] & $\begin{array}{l}\mathrm{ETC} / \mathrm{ACH} \\
\left(60-95^{\circ} \mathrm{C}\right)\end{array}$ & $\begin{array}{l}\text { Techno economic } \\
\text { assessment }\end{array}$ & $\begin{array}{c}\text { Cooling energy cost: } \\
0.0225 € / \mathrm{kWh}_{\mathrm{t}}\end{array}$ & $\begin{array}{l}\text { Cooling capacity: } \\
900 \mathrm{kWh}\end{array}$ \\
\hline [23] & $\begin{array}{c}\text { ETC/ACH (single effect } \\
\left.\mathrm{LiBr} / \mathrm{H}_{2} \mathrm{O}\right) \\
\left(\mathrm{Up} \text { to } 90^{\circ} \mathrm{C}\right)\end{array}$ & $\begin{array}{c}\text { Energy and } \\
\text { economic analysis }\end{array}$ & $\begin{array}{c}\text { Cooling energy: } \\
\text { Abu Dhabi: } 0.0575 € / \mathrm{kWh}_{\mathrm{t}} \\
\text { Rome: } 0.2125 € / \mathrm{kWh}_{\mathrm{t}} \\
\text { Madrid: } 0.1792 € / \mathrm{kWh}_{\mathrm{t}} \\
\text { Thessaloniki: } 0.1771 € / \mathrm{kWh}_{\mathrm{t}}\end{array}$ & $\begin{array}{l}\text { Cooling in a } \\
\text { building with } \\
100 \mathrm{~m}^{2} \text { floor area }\end{array}$ \\
\hline$[24]$ & $\begin{array}{c}\text { Waste heat/ACH/CCH/NGB } \\
\left(70-95^{\circ} \mathrm{C}\right)\end{array}$ & Thermo-economic & $\begin{array}{c}\text { System Payback: } 3.8-4.8 \text { years } \\
\text { COP: } 0.7-0.8\end{array}$ & $\begin{array}{l}\text { Electricity, space } \\
\text { heating, cooling }\end{array}$ \\
\hline [25] & $\begin{array}{l}\text { Solar-assisted/ACH (single } \\
\text { and multi-effect) } \\
\left(70-240^{\circ} \mathrm{C}\right)\end{array}$ & Review & $\begin{array}{l}\text { Solar ACHs cannot compete } \\
\text { economically with } \\
\text { conventional cooling without } \\
\text { government subsidies }\end{array}$ & Cooling \\
\hline [26] & $\begin{array}{c}\text { CPVT/ACH or PVT/ACH } \\
\left(80-95^{\circ} \mathrm{C}\right)\end{array}$ & Modelling, review & $\begin{array}{c}\text { System Payback: } \\
\text { CPVT/ACH (6.1-6.9 years), } \\
\text { PVT/ACH (21-29 years) }\end{array}$ & $\begin{array}{l}\text { Electricity, heating, } \\
\text { cooling }\end{array}$ \\
\hline [27] & $\begin{array}{c}\text { PTC/ORC/ACH } \\
\text { Single effect, } \mathrm{LiBr} / \mathrm{H}_{2} \mathrm{O} \\
\left(235-360^{\circ} \mathrm{C}\right)\end{array}$ & $\begin{array}{l}\text { Energy, exergy and } \\
\text { economic }\end{array}$ & $\begin{array}{l}\text { ACH COP: } 0.57-0.85 \\
\text { Second law efficiency: } \\
21.92-29.42 \%\end{array}$ & $\begin{array}{l}\text { Electricity and } \\
\text { cooling }\end{array}$ \\
\hline [28] & $\begin{array}{c}\mathrm{CPC}^{4} / \mathrm{ACH} / \mathrm{TES}^{5} \\
\text { single, double and variable } \\
\text { effect } \mathrm{LiBr} / \mathrm{H}_{2} \mathrm{O} \\
\left(90-160^{\circ} \mathrm{C}\right)\end{array}$ & Energy, Simulation & $\begin{array}{l}\text { Average COP: } 0.7-1.2 \\
\text { Solar efficiency: } 10-24 \% \\
\text { Storage tank volume has an } \\
\text { important effect on variable } \\
\text { and double effect ACHs }\end{array}$ & Cooling \\
\hline [29] & $\begin{array}{c}\mathrm{CPVT}^{6} / \mathrm{ACH} / \mathrm{PEM} \\
7 / \text { electrolyzer }\left(100^{\circ} \mathrm{C}\right)\end{array}$ & Energy-exergy & Cooling: $0.0649 \$ / \mathrm{kWh}_{\mathrm{t}}$ & $\begin{array}{l}\text { Cooling and } \\
\text { hydrogen }\end{array}$ \\
\hline [30] & $\mathrm{ACH}$ and $\mathrm{CCH}$ & Energy, economic & $\begin{array}{l}\text { ACH energy demand }>\mathrm{CCH} \\
\text { energy demand } \\
\mathrm{ACH} \text { energy cost }<\mathrm{CCH} \\
\text { energy cost }\end{array}$ & Cooling \\
\hline
\end{tabular}


Table 1. Cont.

\begin{tabular}{|c|c|c|c|c|}
\hline Ref. & Technology/Temperature & Modelling/Review & Results & Applications \\
\hline [31] & $\begin{array}{c}\text { Prime mover/NGB }{ }^{8} / \mathrm{ACH} \\
\text { and } \mathrm{CCH}\end{array}$ & $\begin{array}{l}\text { four-E analysis } \\
\text { (energy, exergy, } \\
\text { economy) }\end{array}$ & $\begin{array}{c}\text { System Payback: } 5.1 \text { years } \\
\text { Exergy efficiency of ACH: } \\
41.9 \% \text { for grid on mode and } \\
32.7 \% \text { for grid off mode }\end{array}$ & $\begin{array}{l}\text { Electricity, heating } \\
\text { and cooling } \\
(900-5600 \mathrm{~kW})\end{array}$ \\
\hline [32] & $\begin{array}{c}\text { CPVT/ACH/PEM Fuel Cell } \\
\left(50-90^{\circ} \mathrm{C}\right)\end{array}$ & Energy economic & $\begin{array}{l}\text { The results are in terms of: } \\
\text { Payback time, energy and } \\
\text { economic efficiencies and } \\
\text { utilization factor }\end{array}$ & $\begin{array}{l}\text { heating, cooling, } \\
\text { DHW electricity, } \\
\text { hydrogen, oxygen }\end{array}$ \\
\hline [33] & $\begin{array}{c}\text { PTC/SRC } \\
9 / \mathrm{ACH} / \mathrm{MED} / \mathrm{TES} / \text { process } \\
\text { heat }\left(373^{\circ} \mathrm{C}\right)\end{array}$ & $\begin{array}{l}\text { energy- } \\
\text { economic }\end{array}$ & $\begin{array}{c}\text { Electricity: } \\
\text { 0.1058-0.1220 } \$ / \mathrm{kWh}, \\
\text { Heating: } 0.018-0.03 \$ / \mathrm{kWh} \text {, } \\
\text { Cooling: } 0.036-0.055 \$ / \mathrm{kWh}_{\mathrm{t}} \text {, } \\
\text { fresh water: } 2.746-4.035 \$ / \mathrm{m}^{3}\end{array}$ & $\begin{array}{l}\text { Electricity, heating, } \\
\text { cooling, fresh water }\end{array}$ \\
\hline
\end{tabular}

\begin{tabular}{ccc}
{$[34]$} & Diesel/PV/Wind/Bat & Techno-economic \\
& & \\
\hline$[35]$ & $\begin{array}{c}\text { LF/SRC/MED } \\
\left(395^{\circ} \mathrm{C}\right)\end{array}$ & Techno-economic \\
\hline [36] & LF/SRC/MED and & Exergo-economic \\
& LF/SRO $\left(373^{\circ} \mathrm{C}\right)$ & \\
\hline & $\mathrm{LF} / \mathrm{SRC} / \mathrm{RO}\left(384^{\circ} \mathrm{C}\right)$ & Techno-economic
\end{tabular}

Off-grid systems = 9.3-12.6

Electricity
$[?] / \mathrm{kWh}$

On-grid/Bat system $=5.7-8.4$

[?]/kWh

fresh water: $1.42-1.78 \$ / \mathrm{m}^{3} \quad$ heating

Electricity: $0.15-0.20 \$ / \mathrm{kWh}, \quad$ Electricity and
Fresh water: $1.42 \$ / \mathrm{m}^{3}-2.38 \$ / \mathrm{m}^{3} \quad$ fresh water

\section{For TES $=7.5 \mathrm{~h}:$}

Electricity and fresh water:

$0.19 \$ / \mathrm{kWh}$ and $1.66 \$ / \mathrm{m}^{3}$ for Electricity and

LF/SRC/MED fresh water PTC/SRC/MED

\begin{tabular}{|c|c|c|c|c|}
\hline [38] & $\begin{array}{c}\text { PV/Air source HP, } \\
\text { PV/FPC/Water source HP } \\
\text { and PVT/FPC/Water source } \\
\mathrm{HP}\left(70^{\circ} \mathrm{C}\right)\end{array}$ & $\begin{array}{l}\text { Energy and } \\
\text { economic }\end{array}$ & $\begin{array}{l}\text { PV/Air source heat pump is } \\
\text { more suitable than } \\
\text { PVT/FPC/Water source heat } \\
\text { pump if the electricity cost } \\
\text { would be up to } 0.23 € / \mathrm{kWh}\end{array}$ & Space heating \\
\hline [39] & $\begin{array}{l}\text { Waste heat/ORC/MED } \\
\qquad\left(200^{\circ} \mathrm{C}\right)\end{array}$ & Thermo-economic & $\begin{array}{c}\text { Electricity: } 0.04-0.12 \$ / \mathrm{kWh} \\
\text { and Fresh water:0.8-1.8 } \$ / \mathrm{m}^{3} \\
\text { for production capacities of } \\
500-2000 \mathrm{~m}^{3} / \text { day }\end{array}$ & $\begin{array}{l}\text { Electricity and } \\
\text { fresh water }\end{array}$ \\
\hline [40] & $\begin{array}{l}\text { LF/MED/TVC/TES } \\
\left(256-520^{\circ} \mathrm{C}\right)\end{array}$ & $\begin{array}{l}\text { Techno- } \\
\text { economic }\end{array}$ & $\begin{array}{c}\text { Fresh water: } \\
1.63 \$ / \mathrm{m}^{3}-3.32 \$ / \mathrm{m}^{3} \text { for fresh } \\
\text { water rate of } 9000 \mathrm{~m}^{3} / \text { day }\end{array}$ & Fresh water \\
\hline [41] & $\begin{array}{l}\text { LF/SRC/MED } \\
\left(390{ }^{\circ} \mathrm{C}\right)\end{array}$ & Techno-economic & $\begin{array}{l}\text { Electricity: } 0.16-0.23 \$ / \mathrm{kWh} \\
\text { and Fresh water: } \\
1.85-2.21 \$ / \mathrm{m}^{3} \text { for production } \\
\text { capacities of } 100,000 \mathrm{~m}^{3} / \text { day }\end{array}$ & $\begin{array}{l}\text { Electricity and } \\
\text { fresh water }\end{array}$ \\
\hline [42] & $\begin{array}{c}\text { PTC/SRC/MED } \\
\text { PTC/SRC/RO }\left(377^{\circ} \mathrm{C}\right)\end{array}$ & Techno-economic & $\begin{array}{c}\text { Electricity: } 0.21-0.24 \$ / \mathrm{kWh} \\
\text { and Fresh water: } \\
1.82-2.11 \$ / \mathrm{m}^{3} \text { for } \\
100,000 \mathrm{~m}^{3} / \text { day }\end{array}$ & $\begin{array}{l}\text { Electricity and } \\
\text { fresh water }\end{array}$ \\
\hline [43] & $\begin{array}{c}\text { GT/MED/TVC/RO } \\
\left(120-354^{\circ} \mathrm{C}\right)\end{array}$ & Techno-economic & $\begin{array}{l}\text { Electricity: } 0.018-0.02 \$ / \mathrm{kWh} \\
\text { and Fresh water: } 0.5-0.7 \$ / \mathrm{m}^{3} \\
\text { for } 2000-5000 \mathrm{~m}^{3} / \text { day }\end{array}$ & $\begin{array}{l}\text { Electricity and } \\
\text { fresh water }\end{array}$ \\
\hline
\end{tabular}


The technical and economic performance of the PTC/ORC/TES and PV/Bat was investigated by Patil et al. [44], where the levelized cost of electricity (LCE) and capacity utilization factors (CUFs) of both plants were determined and compared. Based on the results of that study, the LCE of PTC/ORC/TES and PV are obtained as $0.19 \$ / \mathrm{kWh}$ and $0.26 \$ / \mathrm{kWh}$, respectively, for the same CUF of 0.54. However, elimination of the battery storage from the PV plant results in a lower CUF of 0.27 and an attractive LCE of $0.12 \$ / \mathrm{kWh}$ for this system. Awan et al. [45] performed a comprehensive comparison between the COE and other characteristics of the PV and CSP plants. According to that study, the electricity generation of the best case CSP plant was found to be 33.3\% higher than that of the best case PV plant. The CUF of the CSP plant is $45.4 \%$ vs. $30.2 \%$ for the PV plant. For the PV and CSP installed cost of respectively, $1092.87 \$ / \mathrm{kW}$ and $4950.62 \$ / \mathrm{kW}$, the LCE of the CSP and PV were obtained as $0.14 \$ / \mathrm{kWh}$ and $0.0476 \$ / \mathrm{kWh}$. Also, the payback period of the CSP plant was shown to be much more than that of the PV plant; 18.8 years vs. 5 years. Another interesting comparison between the PV and CSP/TES plants is presented in Desideri and Campana [46] for two places located in Italy and Egypt. The LCE of the CSP and PV located in Italy were found as $0.319 € / \mathrm{kWh}$ and $0.190 € / \mathrm{kWh}$, respectively. However, the LCE for the CSP plant located at Egypt was determined as $0.162 € / \mathrm{kWh}$. Also, the electricity efficiency of the PV and CSP plants were obtained as $17.7 \%$ and $10.7 \%$ for the CSP and PV plants, respectively.

\section{Novelty}

To the authors' knowledge, the combination of the LF solar field with the ORC for polygeneration of electricity, heating, cooling and fresh water has been rarely investigated, especially for the Persian Gulf region. In addition, the technical and economic aspects of the PV and LF/ORC have not been compared and presented in any previous research work. Only in [44-46], were comparisons between the electricity cost, CUF or electricity efficiency of the PV and PTC/ORC systems performed. In both [45] and [46] it was concluded that the land factor efficiency of the PV is lower than PTC, however, the LF solar field required less land area than the PTC [47]. The present paper compares the land use efficiency of both PV and LF/ORC plants. Therefore, the aim was to design, analyze and compare two different solar polygeneration systems supplying the heating, cooling, electricity and fresh water for 2000 residents living in 400 apartment units (50 blocks with four floors and two units on each floor) in Bandar-Abbas, a port city located in the south of Iran. Two layouts of the system developed in this work are described in Section 2, and the study area and building specifications are described in Section 3. The model and formulations used to assess the system performance are illustrated in Section 4, providing some details about the components and their operating conditions. The economic model and formulations for two layouts of the system are presented in Section 5. Finally, the results are discussed in terms of the percentage of the annual solar share, unit costs of the electricity, heating, cooling and fresh water and the payback period of the capital investment. A comprehensive sensitivity analysis on the products' unit of costs was performed by changing the fuel cost, the capital costs of LF, $\mathrm{ORC}, \mathrm{ACH}, \mathrm{MED}, \mathrm{PV}, \mathrm{CCH}$ and $\mathrm{RO}$; considering different solar radiation levels of four regions located in the Persian Gulf, Gulf of Aden and Gulf of Oman. Two systems were compared from the economic point of view as well as the technical aspects such as CUF, land use factor, solar fields' electricity efficiencies and the cumulative electricity production over the lifetime of the systems. The results of this paper can be useful in energy planning policies which are related to financial subsidies to renewable energies in the form of the energy incentive or capital subsidy scenarios that can also be of help to Iran government.

\section{System Layout}

Two different scenarios were considered to supply the energy requirements of the described building. Both scenarios can be considered as novel poly generation systems which include different technologies, namely: LF, ORC, ACH and MED/TVC subsystems (in the first scenario) and PV, CCH, RO subsystems (in the second scenario). The main design parameters of the subsystems in both 
scenarios were calibrated in order to achieve the acceptable size of the system to supply part of the total annual electricity, fresh water and space heating and cooling demands of the users. Obviously, the optimal size of the system depends on a number of energy and economic parameters. This is an initial guess value which will be subsequently analyzed by a suitable sensitivity analysis. In the first scenario, the LF solar field output thermal energy was considered to supply the required thermal energy of a double effect ACH, ORC and MED/TVC units of the system. A simplified layout of $\mathrm{LF}_{\mathrm{PS}}$ is shown in Figure 1 . The LF output dry steam at $185^{\circ} \mathrm{C}$ is firstly flowed through an auxiliary Natural Gas Boiler (NGB) and then it is divided into three streams to feed the ACH, ORC and MED/TVC units. The steam thermal energy is transferred into the organic fluid of the ORC and the thermo compressor of the MED unit. A small amount of the fresh water is flowed through a heat exchanger (HE1) to provide the required domestic hot water (DHW) of the users. Part of the electricity that is not consumed by the users is sold to the grid and the thermal energy shortage is compensated by the NGB. For the sake of simplicity in writing, the $\mathrm{LF}_{\mathrm{PS}}$ abbreviation is assigned to the LF/ORC/ACH/MED as the LF polygeneration scenario.

As mentioned before, the layout shown in the previous figure includes a number of innovative components (MED/TVC, LF, ORC). These devices are presently very promising but also extremely expensive. Therefore, in order to perform a suitable comparison, a more mature and cheap layout was also considered. The aim is to compare these two layouts from energy and economic points of view. This secondo layout is represented in Figure $2(\mathrm{PV}$ polygeneration scenario $(\mathrm{PV} \mathrm{PS})$ ). Here the power output of the PV panels were considered to be used for supplying the main electricity load (lighting and appliances) as well as the required electricity of the $\mathrm{CCH}$ and $\mathrm{RO}$ subsystems. Because the high capital cost and low lifespan of the battery system also due to the considerable difference between the electricity demand during the warm and cold months of the year, the application of the battery storage was not considered. The excess electricity is sold to the grid and the electricity shortage of the system would be supplied on the public electricity grid. The NGB was also considered to be included in the system for the low thermal energy that is required for DWH. The PV module was considered to track the Sun on one axis and 12 times per year considering the optimum monthly tilt angles for the PV modules at the study region.

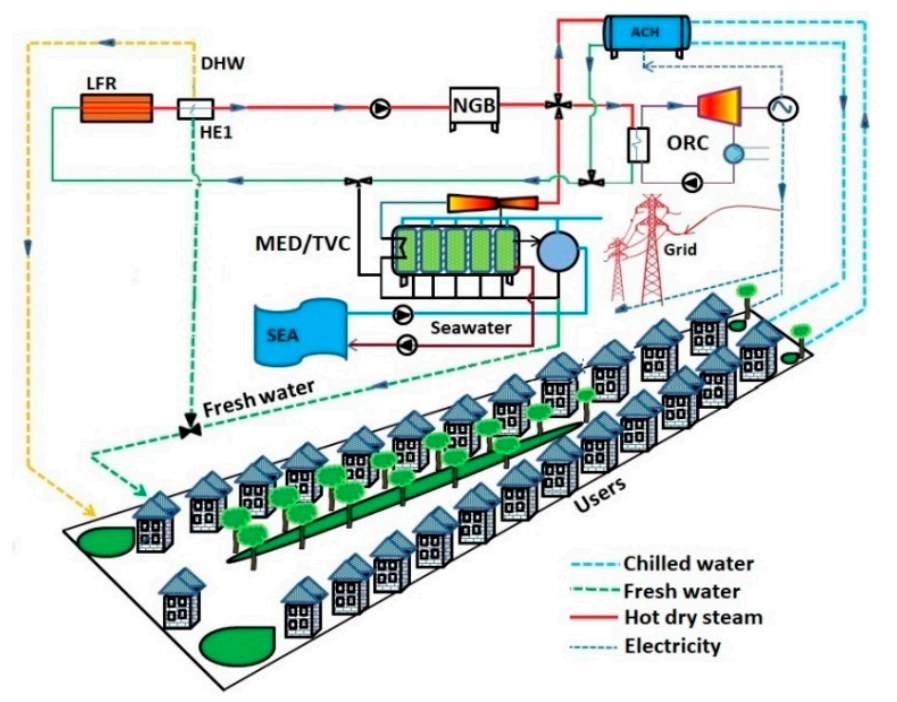

Figure 1. Scenario\#1 (LF/ORC/ACH/MED (LFPS) system without TES). 


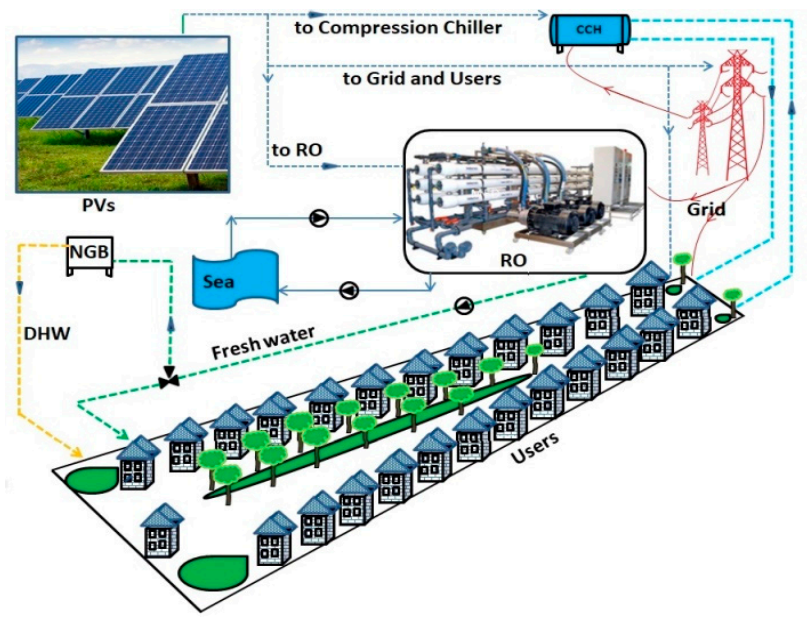

Figure 2. Scenario\#2 (PV/CCH/RO (PV $\mathrm{PS})$ grid-connected system without battery storage).

\section{Study Area and Building Specifications}

The heating energy, cooling energy, electricity and fresh water requirements were designed for 50 apartment blocks, where each block is a four storey building with two $85 \mathrm{~m}^{2}$ units on each floor. The total floor area of each apartment block is $680 \mathrm{~m}^{2}$ with 40 residents considering five residents living in each apartment unit (a total of 2000 residents). For each apartment block, the annual electricity, heating and cooling requirements were calculated using a commercial software tool considering the building specifications such as numbers of floors, directions, numbers of windows, the wall thicknesses, insulation layers, the facade color, numbers of people living in each apartment unit, the interior lighting thermal loads and so forth. The air conditioning system was considered to operate from 2 p.m. to 7 a.m. and the building windows are double glazed with a total area of $18 \mathrm{~m}^{2}$, facing the south and with a U-value of $2.85 \mathrm{~W} / \mathrm{m}^{2} \mathrm{~K}$. In addition, the U-value of external walls, internal walls, roof and floor were considered as $1.01 \mathrm{~W} / \mathrm{m}^{2} \cdot \mathrm{K}, 1.22 \mathrm{~W} / \mathrm{m}^{2} \cdot \mathrm{K}, 0.44 \mathrm{~W} / \mathrm{m}^{2} \cdot \mathrm{K}$ and $0.55 \mathrm{~W} / \mathrm{m}^{2} \cdot \mathrm{K}$ (and $0.743 \mathrm{~W} / \mathrm{m}^{2} \cdot \mathrm{K}$ for the first floor near the unconditioned parking space), respectively. The buildings were considered to be located in the city of Bandar-Abbas which is a port city located on the southern coast of Iran, on the Persian Gulf. The city has a hot desert climate with a maximum annual temperature of $37^{\circ} \mathrm{C}$ in summer and the minimum annual temperature of nearly $15^{\circ} \mathrm{C}$ in winter. The annual rainfall is around $170 \mathrm{~mm}$ and the average relative humidity is $65 \%$. The five years average monthly daily DNI and dry bulb temperature of the region for 12 months of the year were collected from the Iranian Meteorological Organization (IMO) and are shown in Figure 3.

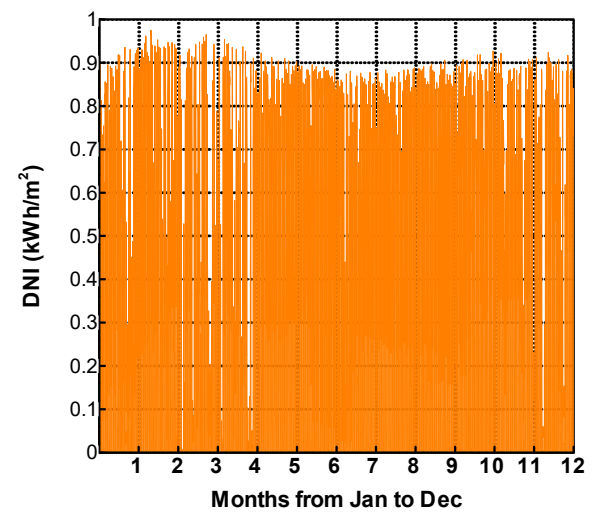

(a) Direct Normal Radiation (DNI)

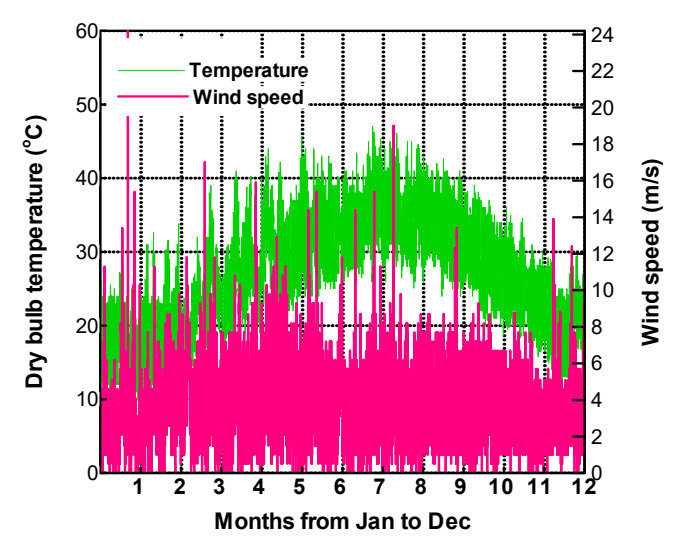

(b) Dry bulb Temperature and wind speed

Figure 3. Average monthly daily DNI and dry bulb temperature of Bandar Abbas. 


\section{System Model}

This part of the study presents the model and the related design parameters of each component of the systems that is used in both scenarios. In order to overcome the off design conditions, the NGB was used in the operation of the polygeneration system in scenario\#1 and for the other scenario, the grid electricity would support the electricity shortages of the PV plant. The modeling and simulations of the system were conducted by different well known software tools. The Carrier Hourly Analysis Program (HAP), which is a powerful tool for designing HVAC systems, was applied for designing and sizing the system components to meet the electricity, cooling and heating energy requirements of the study buildings. The cooling system, which was considered in the present study, comprises of a fan-coil unit with a 2-pipes loop for each zone of the study building as well as a single coil of the chilled water. The thermodynamic modeling of the most significant components of the system in two configurations of the study is only presented in this section:

- The buildings are modelled through HAP, coupled to the AutoCAD 2018 2D drawing model.

- MED/TVC desalination unit. It is modeled through the MATLAB software and it was validated by the commercial MED/TVC plant which is currently operated on Kish Island located in the Persian Gulf. Please refer to the previous study that has been conducted by some authors of the present study for additional details about the modeling of MED/TVC unit [36].

- The thermodynamic modeling of the ORC was performed using Engineering Equation Solver (EES). Based on the critical temperature of pentane (R601), and its good performance within the temperature ranges of $180^{\circ} \mathrm{C}$ to $200^{\circ} \mathrm{C}$, this organic fluid was selected to be used in the ORC.

- The LF solar field and PV plant were modelled using the System Adviser Model (SAM) software provided by U.S. National Renewable Energy Laboratory (NREL) [47].

- The ACH (or $\mathrm{CCH}$ ) were modelled in EES based on the fixed input thermal energy (or required electricity) and considering the specific chilled water and average seawater cooling temperatures of $7{ }^{\circ} \mathrm{C}$ and $30^{\circ} \mathrm{C}$, respectively.

- A simple model was considered for RO desalination unit considering the RO recovery ratio of $45 \%$. For additional details about the modeling of RO unit, please see [36].

The whole system was simulated in MATLAB software based on the hourly electricity, cooling and fresh water requirements of 2000 residents during $8760 \mathrm{~h}$ of the year.

\subsection{Linear Fresnel Model}

The useful thermal energy of the LF at each hour of the year can be calculated using the incident solar radiation on the receiver and considering the hourly thermal losses in the Heat Transfer Fluid (HTF) piping system of the plant:

$$
\mathrm{Q}_{\mathrm{LFR}}=\mathrm{Q}_{\mathrm{in}}-\mathrm{Q}_{\mathrm{hl}_{\mathrm{HTF}}}-\mathrm{Q}_{\mathrm{hl}_{\mathrm{piping}}}
$$

The piping loss $\left(\mathrm{Q}_{\mathrm{h}_{\text {piping }}}\right)$ was considered as $10 \mathrm{~W} / \mathrm{m}^{2}$ of collector aperture area in the present work $[47,48]$. Also the receiver HTF system losses were calculated based on the proposed heat loss model by NREL for evacuated tubes as follows [49]:

$$
\begin{gathered}
\mathrm{Q}_{\mathrm{hl} \_\mathrm{HTF}}=4.05+0.247 \cdot\left(\mathrm{T}_{\mathrm{HTF}}-\mathrm{T}_{\mathrm{amb}}\right)+-0.00146 \cdot \mathrm{T}_{\mathrm{HTF}}^{2}+5.65^{-6} \cdot \mathrm{T}_{\mathrm{HTF}}^{3} \\
+7.62^{-8} \cdot \mathrm{IAM}_{\mathrm{t}} \cdot \mathrm{IAM}_{\mathrm{L}} \cdot \mathrm{T}_{\mathrm{HTF}}^{4}+\sqrt{\mathrm{V}_{\mathrm{w}}} \cdot\left(-1.7+0.0125 \cdot\left(\mathrm{T}_{\mathrm{HTF}}-\mathrm{T}_{\mathrm{amb}}\right)\right)
\end{gathered}
$$

$\mathrm{IAM}_{\mathrm{t}}$ and $\mathrm{IAM}_{\mathrm{L}}$ were considered to determine reductions in the optical efficiency of the collector that is occurred due to the deviation of solar radiation incident angle in the transversal and longitudinal planes. The incidence solar thermal energy in Equation (1) was calculated based on the DNI, incidence angle on the collector $\left(\theta_{\mathrm{i}}\right)$, collector area $\left(\mathrm{A}_{\text {field }}\right)$ and the tube absorber and the receiver length $(\mathrm{L})$ as follows: 


$$
\mathrm{Q}_{\text {in }}=0.65 \times \mathrm{IAM}_{\mathrm{t}} \times \mathrm{IAM}_{\mathrm{L}} \times\left(1-\tan \theta_{\mathrm{i}} \times \frac{\mathrm{L}_{\mathrm{f}}}{\mathrm{L}}\right) \times \mathrm{A}_{\text {field }} \times \mathrm{DNI}
$$

Readers may refer to [47] for further information regarding the LF useful solar thermal power calculations. A linear Fresnel collector with different loops, and 13 modules implemented in each loop (total loop surface area of $6676.8 \mathrm{~m}^{2}$ ) was considered in this paper [40].

The amount of annual solar thermal energy that is produced and used in supplying the required thermal energy of the system is divided by the total annual required thermal load of the plant $\left(Q_{\text {need }}\right)$, and represents the Solar Fraction (SF, \%):

$$
\mathrm{SF}=\frac{\sum_{\mathrm{t}=1}^{\mathrm{t}=8760} \mathrm{Q}_{\text {sol }}(\mathrm{t})}{\sum_{\mathrm{t}=1}^{\mathrm{t}=8760} \mathrm{Q}_{\text {need }}(\mathrm{t})} ; \mathrm{Q}_{\text {sol }}(\mathrm{t}) \leq \mathrm{Q}_{\text {need }}(\mathrm{t})
$$

where, $Q_{\text {sol }}$ is the hourly LF solar thermal energy that is used to supply the hourly required thermal energy of the system $\left(Q_{\text {need }}(t)\right)$. If the solar thermal power is higher than the corresponding user demand, the extra solar thermal energy is used by the ORC to produce further electricity which was assumed to be sold to the grid. Therefore, the solar thermal extra fraction is defined as the fraction of the yearly excess solar thermal energy, which is used to generate the electricity by the ORC, to the $\mathrm{Q}_{\text {need }}$ of the system:

$$
\mathrm{EF}=\frac{\sum_{\mathrm{t}=1}^{\mathrm{t}=8760} \mathrm{Q}_{\text {sol }}(\mathrm{t})}{\sum_{\mathrm{t}=1}^{\mathrm{t}=8760} \mathrm{Q}_{\text {need }}(\mathrm{t})} ; \mathrm{Q}_{\text {sol }}(\mathrm{t}) \geq \mathrm{Q}_{\text {need }}(\mathrm{t})
$$

Similarly, part of the solar thermal energy that is higher than the required thermal energy of the ORC because of its specific nominal power was considered as the wasted thermal energy. The fraction of total annual wasted solar thermal energy to the $Q_{\text {need }}$ of the system was defined as the wasted fraction:

$$
\mathrm{WF}=\frac{\sum_{\mathrm{t}=1}^{\mathrm{t}=8760} \mathrm{Q}_{\text {sol }}(\mathrm{t})}{\sum_{\mathrm{t}=1}^{\mathrm{t}=8760} \mathrm{Q}_{\text {need }}(\mathrm{t})} ; \mathrm{Q}_{\text {sol }}(\mathrm{t})>\mathrm{Q}_{\mathrm{ORC}}(\mathrm{t})>\mathrm{Q}_{\text {need }}(\mathrm{t})
$$

\subsection{MED/TVC Model}

The MED scale was determined based on the daily fresh water requirements of the residents. The required fresh water rate of $200 \mathrm{~m}^{3} /$ day was considered for 2000 people who are living in the 50 apartment units. A parallel cross flow MED unit with five effects, a TVC and gain output ratio (GOR) of 8.5 was used in the calculations of the present paper. This type of MED/TVC system is currently used on Kish Island located in the Persian Gulf [50]. A detailed model of the MED unit can be found in previous research by the authors of the present study $[36,40]$. The average seawater temperature and salinity were considered as $35^{\circ} \mathrm{C}$ and 45,000 ppm based on the average annual sweater temperature of the region and the Persian Gulf seawater salinity [51,52]. The last effect temperature and resultant brine salinity were considered as $40^{\circ} \mathrm{C}$ and 72,000 ppm, respectively. The following equation was used to determine the amount of required mass flow rate of the steam that should be flowed through the TVC as the motive steam $\left(\dot{m}_{\mathrm{SF}_{\mathrm{MED}}}\right)$ according to the MED fresh water capacity of $2.31 \mathrm{~kg} / \mathrm{s}\left(200 \mathrm{~m}^{3} / \mathrm{day}\right)$ :

$$
\mathrm{GOR}=\frac{\dot{\mathrm{m}}_{\mathrm{D}}}{\dot{\mathrm{m}}_{\mathrm{SF} \mathrm{MED}}}
$$

where, $\dot{\mathrm{m}}_{\mathrm{D}}$ and $\dot{\mathrm{m}}_{\mathrm{SF}} \mathrm{MED}$ are the MED fresh water and the motive steam mass flow rates, respectively. $\dot{m}_{S F_{M E D}}$ is the mass flow rate of that part of the LF output steam that should be flowed into the TVC. For the time when the solar thermal energy is low or during its non-availability, the NGB supplies the thermal energy shortage of the system. The input and output temperature of the MED/TVC unit from the thermal source side are $185^{\circ} \mathrm{C}$ and $70^{\circ} \mathrm{C}$, respectively, at saturated steam pressure of 1123.5 $\mathrm{kPa}$. Applying the above relationships, the required $\dot{\mathrm{m}}_{\mathrm{SF}_{\mathrm{MED}}}$ is obtained as $0.27 \mathrm{~kg} / \mathrm{s}$. The electricity consumption of the MED unit was considered as $1.55 \mathrm{kWh} / \mathrm{m}^{3}$ [36]. The specific heat consumptions of 
the MED unit is defined as the amount of heat that is required for producing $1 \mathrm{~m}^{3}$ of fresh water and it is calculated as follows [53]:

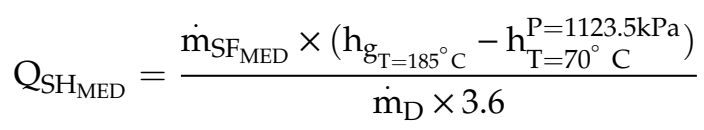

where, the $\mathrm{Q}_{\mathrm{SH}}$ MED is obtained as $65 \mathrm{kWh} / \mathrm{m}{ }^{3}$ considering the GOR of 8.5 for the MED/TVC unit of the present study. This value was used to calculate part of the unit cost of the water which is associated with the thermal energy unit cost that is generated by LF solar field.

\subsection{ORC Model}

The ORC expander and condenser were considered to be operated at $180^{\circ} \mathrm{C}$ and $45^{\circ} \mathrm{C}$, respectively, considering $5{ }^{\circ} \mathrm{C}$ temperature drop in the ORC heat exchanger. The ORC scale was determined based on the maximum required electricity by the user which is equal to $6500 \mathrm{~kW}$ as it is shown in Figure 4 . A computer program was developed in Engineering Equations Solver (EES) to calculate the ORC efficiency ( $\eta_{\mathrm{ORC}}$ ) considering the R601 as the organic fluid. For the ORC turbine inlet temperature of $180^{\circ} \mathrm{C}$ and considering the condenser temperature of $45^{\circ} \mathrm{C}$, the ORC efficiency is obtained as $15.95 \%$ which is in a good agreement with that has been reported in [54].

$$
\begin{aligned}
& \dot{\mathrm{Q}}_{\mathrm{ORC}}=\dot{\mathrm{m}}_{\mathrm{SF}_{\mathrm{ORC}}} \times\left(\mathrm{h}_{\mathrm{g}_{\mathrm{T}=185}{ }^{\circ} \mathrm{C}}-\mathrm{h}_{\mathrm{T}=70{ }^{\circ} \mathrm{C}}^{\mathrm{P}=1123 \mathrm{~Pa}}\right) \times \varepsilon=\dot{\mathrm{m}}_{\mathrm{ORC}} \times\left(\mathrm{h}_{\mathrm{in}, \mathrm{ORC}}-\mathrm{h}_{\mathrm{out}, \mathrm{ORC}}\right) \\
& \eta_{\mathrm{ORC}}=\frac{\dot{\mathrm{W}}_{\mathrm{ORC}}}{\dot{\mathrm{Q}}_{\mathrm{ORC}}}
\end{aligned}
$$

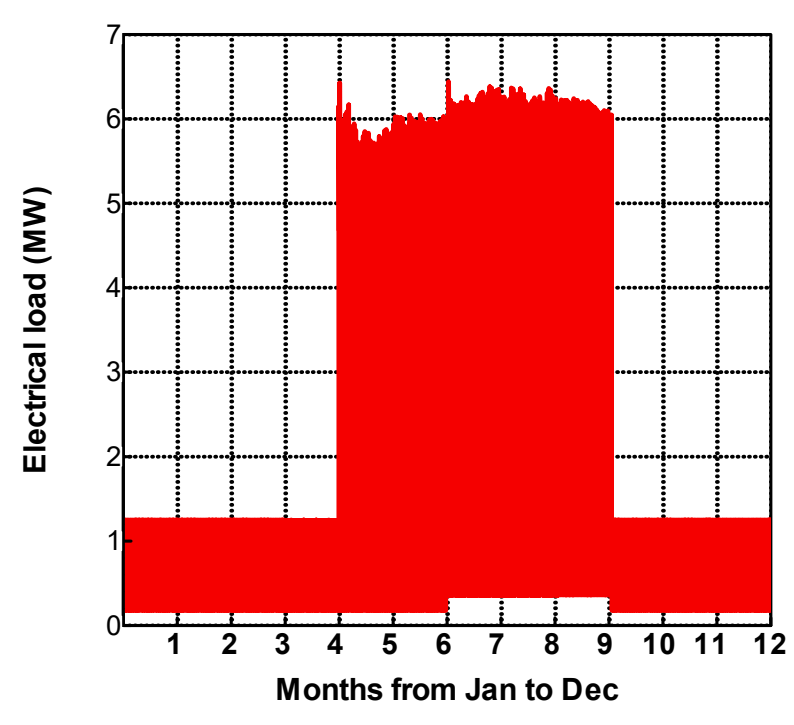

Figure 4. Required ORC thermal energy.

\subsection{Chiller Models}

For the two scenarios of the study, two types of chillers were considered for supplying the cooling energy of the buildings. The COPs of 1.2 and 3 were considered for the double effect $\mathrm{LiBr} / \mathrm{H}_{2} \mathrm{O} \mathrm{ACH}$ (Table 2) and electrical CCH systems, respectively. A capacity of $7500 \mathrm{~kW}$ was considered based on the required cooling capacity of the air-conditioning system during the summertime. Because the high relative humidity and dry bulb temperature of the region during the warm months, the once through cooling technology was considered to cool down the chiller condensers due to the low distance between the buildings and the sea. The $\mathrm{ACH}$ required thermal energy and $\mathrm{CCH}$ electricity demand 
were calculated based on their COPs, required cooling load of the system and assuming the average seawater temperature of $30^{\circ} \mathrm{C}$ for the warm months as follows:

$$
\begin{gathered}
\dot{\mathrm{Q}}_{\mathrm{h}, \mathrm{ACH}}=\frac{\dot{\mathrm{Q}}_{\text {cooling }}}{\mathrm{COP}_{\mathrm{ACH}}} \\
\dot{\mathrm{Q}}_{\text {cooling }}=\dot{\mathrm{m}}_{\mathrm{ACH}_{\mathrm{W}}} \times\left(\mathrm{h}_{\mathrm{in}, \mathrm{ACH}}-\mathrm{h}_{\mathrm{out}_{\mathrm{ACH}} \mathrm{AC}}\right)
\end{gathered}
$$

The effectiveness of the $\mathrm{ACH}$ heat exchanger was assumed as 0.65 in the calculations of the present study $[55,56]$. The following equation was used to calculate the $\mathrm{CCH}$ hourly electricity consumption:

$$
\dot{\mathrm{W}}_{\mathrm{CCH}}=\frac{\dot{\mathrm{Q}}_{\text {cooling }}}{\mathrm{COP}_{\mathrm{CCH}}}
$$

Table 2. The specification of the ACH that were used in the calculations for Bandar Abbas.

\begin{tabular}{rc}
\hline $\mathrm{T}_{\text {in,Chw,rated,ACH Inlet chilled water rated temperature }}$ & $1{ }^{\circ} \mathrm{C}$ \\
Chilled water set-point temperature & $7{ }^{\circ} \mathrm{C}$ \\
$\mathrm{T}_{\text {in,cool,rated,ACH Inlet cooling water rated temperature }}$ & $30^{\circ} \mathrm{C}$ \\
$\mathrm{T}_{\text {out,cool,rated,ACH Outlet cooling water rated temperature }}$ & $35^{\circ} \mathrm{C}$ \\
$\mathrm{T}_{\text {in,hot,rated,ACH Inlet hot water rated temperature for ACH operation }}$ & $180{ }^{\circ} \mathrm{C}$ \\
$\mathrm{T}_{\text {out,hot,rated,ACHOutlet hot water rated temperature for ACH operation }}$ & $70{ }^{\circ} \mathrm{C}$ \\
Chilled water flowrate (pump P3) & $359 \mathrm{~kg} / \mathrm{s}$ \\
Cooling water flow rate (pump P2) & $780 \mathrm{~kg} / \mathrm{s}$ \\
Hot water flow rate (pump P1) & $2.64 \mathrm{~kg} / \mathrm{s}$ \\
COP & 1.2 \\
Rated cooling capacity & $7500 \mathrm{~kW}$ \\
Rated Heat Input & $6250 \mathrm{~kW}$ \\
\hline
\end{tabular}

\subsection{NGB}

An auxiliary boiler was considered to supply the thermal energy shortage of the system during the none-availability of solar thermal energy. The natural gas fuel was considered to be consumed by the NGB at the low price of $0.03 \$ / \mathrm{m}^{3}$. The amount of thermal energy that is generated by NGB was calculated from the following equations:

$$
\mathrm{Q}_{\mathrm{NGB}}=\frac{\mathrm{Q}_{\text {shortage }}}{\eta_{\mathrm{Hex}}}=\frac{\dot{\mathrm{m}}_{\mathrm{SF}} \times\left(\mathrm{h}_{\mathrm{T}=185^{\circ} \mathrm{C}}-\mathrm{h}_{\mathrm{out}, \mathrm{SF}}\right)}{\eta_{\mathrm{Hex}}} ;\left(\mathrm{h}_{\mathrm{out}, \mathrm{SF}}<\mathrm{h}_{\mathrm{T}=185^{\circ} \mathrm{C}}\right)
$$

where, $\eta_{\text {Hex }}$ is the efficiency of the NGB that was assumed to be $90 \%, \mathrm{~h}_{\mathrm{out}, \mathrm{SF}}$ is the enthalpy of the steam at the outlet of the solar field.

\subsection{PV Model}

The output power of the PV modules is depended on different parameters such as solar energy received by PV panels, tilt angle and orientation of the PVs, cloudiness factor, the ground reflectance, total area of the PV modules, the module reference efficiency, the packing factor and the power conditioning efficiency [57-60]. The calculations of the PV output power were performed using SAM software [47]. The PV modules were assumed to have a one axis tracking system. The PV system losses due to factors such as soiling, shading, mismatch, wiring, connections, nameplate limits and availability were totally considered as $15 \%$ of total electricity that is generated by the system. Different models for calculating the output PV power are proposed and used in the SAM software. The single-point efficiency model calculates the output DC power of the PV modules as follows:

$$
\mathrm{P}_{\mathrm{DC}}=\mathrm{I}_{\mathrm{t}} \times \mathrm{A}_{\mathrm{PV}} \times \eta_{\mathrm{PV}} \times \mathrm{F}_{\mathrm{T}} \text { corr }
$$


where, $I_{t}, A_{P V}$ and $\eta_{P V}$ are the total incident global radiation $\left(W / \mathrm{m}^{2}\right)$, module area $\left(\mathrm{m}^{2}\right)$ and PV efficiency, respectively. $\mathrm{F}_{\mathrm{T} \text {, corr }}$ is the temperature correction factor. Please see Ref. [47] for detail explanations on the PV model.

The long shadows are produced in a PV system during late afternoon or early morning in winter solstice. The approach shown in [45] was applied to calculate the optimal distance $d_{\text {opt }}$ between parallel rows at which the mutual shading losses are not occurred. The optimal distance between the parallel strings can be obtained using the following equation [44,45]:

$$
\mathrm{d}_{\mathrm{opt}}=\frac{\left(\mathrm{h}+\mathrm{h}_{\mathrm{f}}\right)}{\sin \alpha_{\mathrm{p}}} \sin \left(180-\alpha_{\mathrm{p}}-\beta\right)
$$

where, $h_{f}$ is the height of concreate foundations which was considered as $0.25 \mathrm{~m} . \alpha_{p}$ and $\beta$ are the projected solar altitude angle and the maximum tilt angle for early or late hour in a December day, respectively. $\alpha_{\mathrm{p}}$ is calculated using the solar azimuth angle, $\gamma_{\mathrm{s}}$ and the azimuth angle of the PV surface, $\gamma$ :

$$
\alpha_{\mathrm{p}}=\tan ^{-1}\left[\frac{\left(\tan \alpha_{\mathrm{s}}\right)}{\operatorname{cosin}\left(\gamma_{\mathrm{s}}-\gamma\right)}\right]
$$

The overall solar electric efficiency, $\eta_{\mathrm{o}, s_{-} \mathrm{e}}$ and the land use factor, $F$ were determined using the following equations:

$$
\begin{gathered}
\eta_{\mathrm{o}, \mathrm{s} \_\mathrm{e}}=\frac{\mathrm{E}_{\mathrm{el}}}{\mathrm{E}_{\mathrm{sol}}} \\
F=\frac{\mathrm{A}_{\mathrm{sf}}}{\mathrm{A}_{\text {land }}}
\end{gathered}
$$

where, $\mathrm{E}_{\mathrm{el}}$ and $\mathrm{E}_{\mathrm{sol}}$ are the total electricity that is generated by solar (LF/ORC or PV) and the total available solar energy on the solar field, respectively. $\mathrm{A}_{\mathrm{sf}}$ is the total LF mirrors aperture area or PV surface area and $A_{\text {land }}$ is the total required land area for the solar field. The LF solar field mirror aperture area is nearly equal to its total required land area [46]. In a typical LF/Rankine cycle plant, the solar field aperture area is multiplied by the coefficient 1.4 in order to calculate the total solar field and no solar field required land area of the plant [37]. Since the ORC plant size is shorter than the Rankine cycle power block, in the present study, the non-solar field land area multiplier was considered as 1.35. For the PV solar field, the land use factor, F is determined using $\mathrm{d}_{\mathrm{opt}}$, the PV maximum tilt angle for early or late hour in a December day, $\beta$ and the PV module length of $1.66 \mathrm{~m}$ as follows:

$$
\mathrm{F}=\left(1.66 \times \cos (\beta) / \mathrm{d}_{\mathrm{opt}}\right) \text { for } \mathrm{PV} \mathrm{PS}
$$

The capacity utilization factor which is the ratio of total annual solar electricity that is produced by the system to the total annual electricity that plant would generate at its full capacity during the year:

$$
\mathrm{CUF}=\frac{\mathrm{E}_{\mathrm{sf}, \text { annual }}}{\mathrm{E}_{\mathrm{sf}, \text { nameplate }, 8760 \mathrm{~h}}}
$$

\subsection{RO Model}

The RO desalination plant comprises different components such as high pressure pumps, membranes, media filters, cartridges filters, energy recovery device and so forth. The average specific electricity consumption in the conventional SWRO plants that are located in the Persian Gulf with the seawater salinity of $46,000 \mathrm{ppm}$ is approximately equal to $4.2 \mathrm{kWh} / \mathrm{m}^{3}$ of permeate $[36,42]$. However, for the SWRO desalination plants that are located in the Mediterranean Sea with a salinity of $35,000 \mathrm{ppm}$ it has been reported as $3.5 \mathrm{kWh} / \mathrm{m}^{3}$ of produced permeate [61]. The recovery ratio is defined as the ratio of the produced permeates $\left(\mathrm{m}^{3}\right)$ to the intake seawater $\left(\mathrm{m}^{3}\right)$ that is flowed into the RO system [62]. In the present study, the specific electricity consumptions of $4.2 \$ / \mathrm{kWh}$ and the recovery ratio of $45 \%$ were considered in the calculations of the $\mathrm{RO}$ plant [42]. The required electricity 
of the SWRO unit was calculated by multiplying the amount of required fresh water by the specific electricity consumptions of the plant as follows:

$$
\dot{\mathrm{W}}_{R O}=\text { Permeate }\left(\mathrm{m}^{3}\right) \times 4.2 \mathrm{kWh} / \mathrm{m}^{3}
$$

\section{Economic Analysis}

An economic analysis is required to determine the unit cost of the electricity, fresh water, cooling and heating energy that are produced in each scenarios of the study. The capital cost, operational and maintenance costs, spare part replacement costs, contingency overhead costs, labor and insurance costs are included in the economic consideration of the energy systems. The capital costs of the system can be converted into the annual costs using the capital recovery factor (CRF) over the project lifetime. Four definitions of levelized cost of electricity (LCE), levelized cost of water (LCW), levelized cost of heating energy $(\mathrm{LCH})$ and levelized cost of cooling energy (LCC) were considered to determine the unit costs of the electricity, fresh water, heating energy and cooling energy that are produced by the system. In the appendix section, Tables A1 and A2 show the equations of LCH, LCC, LCE and LCW for the two scenarios of the study. The other costs of the system components included in two scenarios are reported in Table A3. Part of the unit costs of the products which are related to the NGB capital cost and fuel prices can be much lower than the other part which is associated with the solar energy costs due to the high subsidized fuel prices in Iran. Therefore, part of the unit costs that are associated with the solar energy was used to find the optimum configurations of the system with the minimum costs. The simple payback (SPB) index and the internal rate of return (IRR) were used to evaluate the economic performance of the proposed systems [14]:

$$
\mathrm{SPB}=\frac{\mathrm{Z}_{\text {total }}}{\left[\operatorname{Re}_{\mathrm{el}}+\operatorname{Re}_{\mathrm{fw}}+\operatorname{Re}_{\mathrm{H}}+\operatorname{Re}_{\mathrm{C}}\right]_{\text {Soled to users }}^{\text {solar }}+\left[\operatorname{Re}_{\mathrm{el}}\right]_{\text {Soled to grid }}^{\text {solar }}-\mathrm{Z}_{\mathrm{O} \& \mathrm{M}}}
$$

where, $Z_{\text {total }}$ is the total capital costs of the system components which is different for two scenarios of the study:

$$
\begin{gathered}
Z_{\text {total }}=Z_{\mathrm{LF}}+Z_{\mathrm{ACH}}+\mathrm{Z}_{\mathrm{ORC}}+\mathrm{Z}_{\mathrm{MED}} \quad \text { Scenario\#1 } \\
\mathrm{Z}_{\text {total }}=\mathrm{Z}_{\mathrm{PV}}+\mathrm{Z}_{\mathrm{CCH}}+\mathrm{Z}_{\mathrm{RO}} \quad \text { Scenario\#2 }
\end{gathered}
$$

The internal rate of return is the discount rate that causes the net present value (NPV) of a project to be equal to zero:

$$
\mathrm{NPV}=\sum_{\mathrm{n}=0}^{\mathrm{N}} \frac{\mathrm{CF}_{\mathrm{n}}}{(1+\mathrm{RR})^{\mathrm{n}}}=0
$$

where, $\mathrm{CF}_{\mathrm{n}}$ is the net cash inflow-outflows during a single period of $\mathrm{N}$.

\section{Results and Discussion}

For both scenarios, the sizes of the LF solar field or PV plant were determined based on the amount of the thermal energy or electricity requirements of the system components. For the LF solar field, the numbers of required LF modules were calculated based on the DNI of the region, area of the modules, the specified input and output temperature of $70{ }^{\circ} \mathrm{C}$ and $185{ }^{\circ} \mathrm{C}$ respectively for the solar field as well as the required thermal energy and mass flow rate that should be assigned into the system components. Also, in the calculations of scenario\#2, the required electricity demand of the system, which includes the electricity consumptions of $\mathrm{CCH}, \mathrm{RO}$, pumps and lightening were firstly determined. Then, PV capacity was specified based on the electricity demand. 


\subsection{Scenatrio\#1, $L F_{P S}$}

The total hourly required thermal load of the ACH, DHW, ORC and MED were calculated based on the formulations that are presented in the former sections and is depicted in Figure 5. As is clear in this figure, the main part of the total thermal requirements of the system is related to the ORC and during the warm months when the required electricity of the air conditioning system is high. For cold months of the year, because the relatively moderate ambient temperature of the region (Figure 3), there is no space heating requirements and the thermal energy is associated with the DWH and ORC. Since the difference between the required thermal energy of the warm and cold months is high, the application of the TES seems not to be a suitable alternative. Therefore, it was assumed that the thermal energy and electricity shortage are supplied by the NGB and grid electricity, respectively. The excess electricity that is produced by the ORC is sold to the grid to compensate part of the electricity costs of the system that is purchased from the grid.

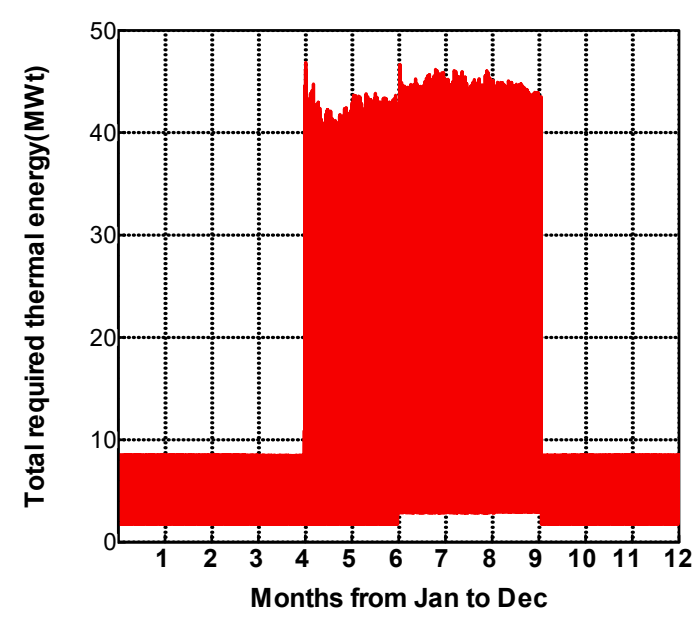

Figure 5. Required thermal energy, $\mathrm{LF}_{\mathrm{PS}}$.

In order to determine the optimum size of the LF solar field, the calculations were performed for different numbers of LF modules. In the LF solar field, there are two alternatives to control the output temperature of the field; changing the steam mass flow rate or defocusing the mirrors [40,41]. The LF output thermal power for one loop was calculated based on the specific input and output temperatures of respectively $70^{\circ} \mathrm{C}$ and $180^{\circ} \mathrm{C}$ using SAM software. Then, the SAM output was used in a computer program, which was developed in MATLAB, in order to calculate the amount of annual solar thermal energy that is produced and used in supplying the required thermal energy of the system as well as the mass flow rate of the solar field.

\subsubsection{LF Solar Field}

The calculations were performed for different numbers of the LF loops (NL) with the surface area of equal to $6676.8 \mathrm{~m}^{2}$ for each loop. By increasing the surface area of the SF mirrors it is possible to increase the contribution of the solar thermal energy in supplying the total annual required thermal power of the system (SF, \%). Based on the results of the former sections regarding the solar field mass flow rates that are assigned to the MED, ACH and ORC, the total required heating steam mass flow rate was considered as $25.73 \mathrm{~kg} / \mathrm{s}$. In this part of the study, the variations of the annual SF and WF of the system versus the solar field numbers of loops (NLs) were calculated and shown in Figure 6 for the Bandar-Abbas, Iran. As can be seen, by increasing of the NLs, the SF would be increased. However, the further increasing in the NLs for more than a specific number results in increasing the wasted solar thermal fraction (WF, \%) and has no considerable effect on the SF of the plant. Considering $0.62 \%$ of the annual WF for nine NLs in the field (aperture area of $0.060 \mathrm{~km}^{2}$ ) and the ORC rated power of 6.5 MW, the SF of the system would be obtained as $32.20 \%$. In such case, the increasing of NLs for more 
than nine would result in an increase in the amount of solar thermal energy that cannot be used to further supply the total annual required thermal load. Therefore, the SF of the system would be slightly increased and as consequence, the percentage of WF is increased for the NLs of more than nine.

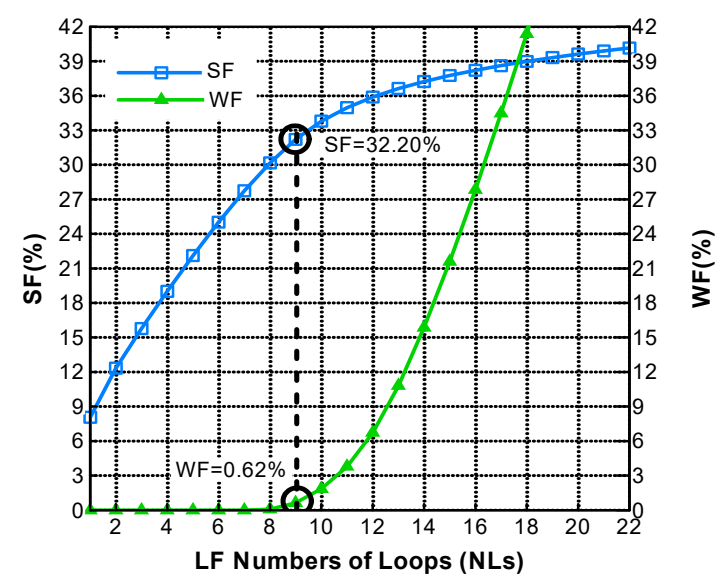

Figure 6. the variations of the wasted solar thermal energy fraction versus solar field NLs.

The system with nine NLs was selected and the calculations were followed to obtain different specifications of the system as well as the system unit costs of the products. The total daily values of the produced solar thermal energy $\left(Q_{\text {sol }}\right)$, required thermal load $\left(Q_{\text {need }}\right)$, the amount of supplied thermal load $\left(Q_{\text {supplied }}\right)$, the excess solar thermal energy $\left(Q_{\text {excess }}\right)$ and the wasted solar thermal energy $\left(Q_{\text {wasted }}\right)$ for the configuration with 9 NLs are shown in Figure 7. As can be seen, the solar field maximum daily thermal energy is equal to $400 \mathrm{MW}$ which is lower than the maximum daily required thermal energy of the system $(630 \mathrm{MWt})$. Because of the low amount of $Q_{\text {need }}$ during the cold seasons, a large part of the solar field thermal energy is higher than the required daily thermal load of the system and this part ( $Q_{\text {excess}}$ ) would be used in the ORC to produce the electricity which was considered to be sold to the grid. It is evident that for the worm months with high amount of required thermal energy, the excess solar thermal energy that is used in the ORC is lower than that for the cold months. Because a TES was not considered in the present work, even during the cold seasons with high amount of excess solar thermal energy, part of the required thermal load of the system cannot be supplied by the solar field. Figure 7 also shows that the low part of the daily solar thermal energy is wasted during the year for $0.62 \%$ of WF which was considered to have the SF of $32.20 \%$ as it is also shown in Figure 6.

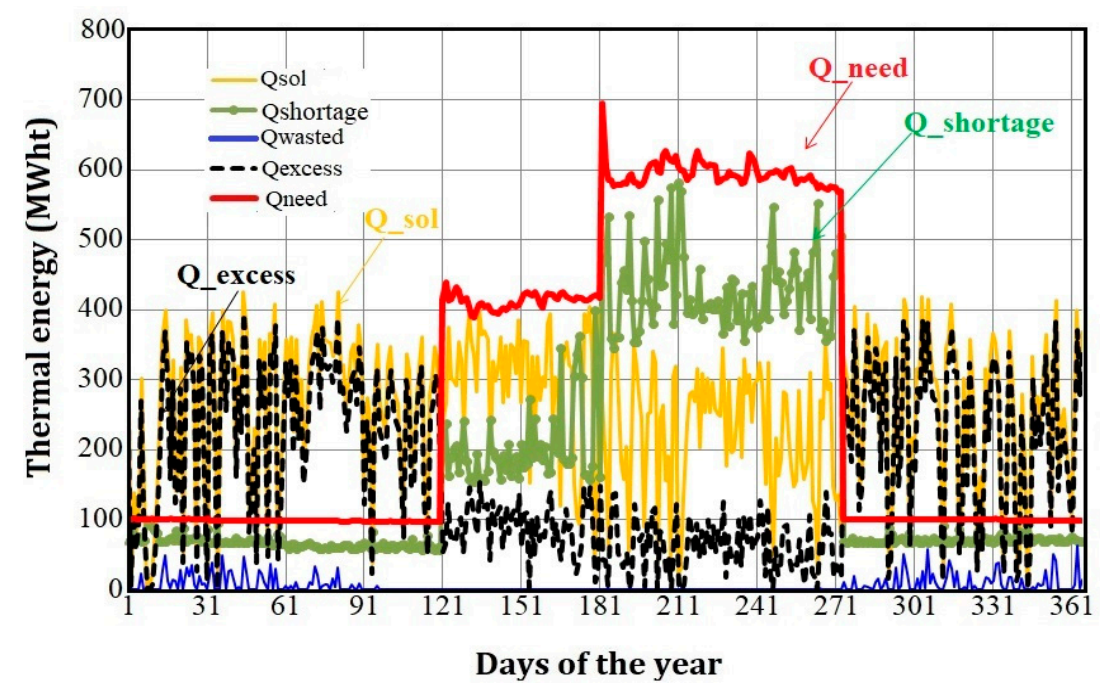

Figure 7. The daily required thermal load and solar thermal energy that is useful or wasted. NLs $=10$, $\mathrm{SF}=32.20 \%, \mathrm{WF}=0.62 \%$. 
The heating energy unit of cost that depends on the solar field costs is the main parameter that affects the cooling energy, electricity and fresh water unit costs. As mentioned above in the economic model, the unit cost of heating energy depends on the thermal energy sources of the system (solar/fuel). Therefore, unit costs of the produced heating energy, cooling energy, electricity and fresh water are different depending on which thermal source is considered in the calculations. In the present work, the unit costs of the products were firstly calculated for the system with solar thermal or fuel thermal sources and the final costs of the products were calculated based on both thermal sources of the system (Appendix A, Equations (1a)-(12a)). The unit costs of the products for the solar and fuel thermal energy sources were calculated considering the system with the ORC rated power of $6.5 \mathrm{MW}$ for NLs $=9, \mathrm{SF}=32.20 \%, \mathrm{WF}=0.62 \%$ as it is shown in Table 3 . As can be seen, the unit cost of heating energy for the solar field is equal to $0.013 \$ / \mathrm{kWh}_{\mathrm{t}}$ which is nearly 4.33 -fold the fuel-based heating energy unit of cost. Also, the average unit cost of the heating energy, which was obtained based on the SF and the NGB thermal energy share (Appendix A, Equation (1a)), is obtained as $0.006 \$ / \mathrm{kWh}_{\mathrm{t}}$; approximately equal to $46 \%$ of the solar-based heating energy unit of cost. Similarly, the fuel-based and the solar/fuel average cooling energy units of costs are obtained as $44.57 \%$ and $61.44 \%$ of that obtained for the solar thermal energy $\left(0.083 \$ / \mathrm{kWh}_{\mathrm{t}}\right)$. The difference between the LCE $\mathrm{sol}(0.249 \$ / \mathrm{kWh})$ and $\mathrm{LCE}_{\text {fuel }}$ $(0.228 \$ / \mathrm{kWh})$ is low due to the fact the same ORC capital cost that was considered in the calculations of these two parameters (Appendix A, Equations (8a,9a)). Besides, the total annual electricity generation of the solar-based ORC cycle (11812 MWh) is higher than that of the NGB-based cycle (9508 MWh). Please see Figure 8 for the daily electricity load and output powers of the ORC with solar and fuel thermal energy sources. In Table 3, the unit cost of fresh water which is produced using solar thermal energy is obtained as $\left(2.540 \$ / \mathrm{m}^{3}\right)$, which is 2-fold that obtained for the MED with fuel thermal source. This high value of $\mathrm{LCW}_{\text {sol }}$ is obtained because of the high unit of cost of solar-based heating energy $\left(\mathrm{LCH}_{\mathrm{sol}}\right)$. The portions of thermal energy cost, MED capital cost, electricity cost and maintenance costs in total $\mathrm{LCW}_{\text {sol }}$ are respectively equal to $40.10 \%, 32.30 \%, 15.20 \%$ and $12.40 \%$. These portions are $17.67 \%, 30.80 \%, 26.70 \%$ and $24.83 \%$ for the fuel-based fresh water unit of cost $\left(\mathrm{LCW}_{\text {fuel }}\right)$. The average unit cost of fresh water was also calculated and it is equal to $1.678 \$ / \mathrm{m}^{3}$ as it can be seen from Table 3 .

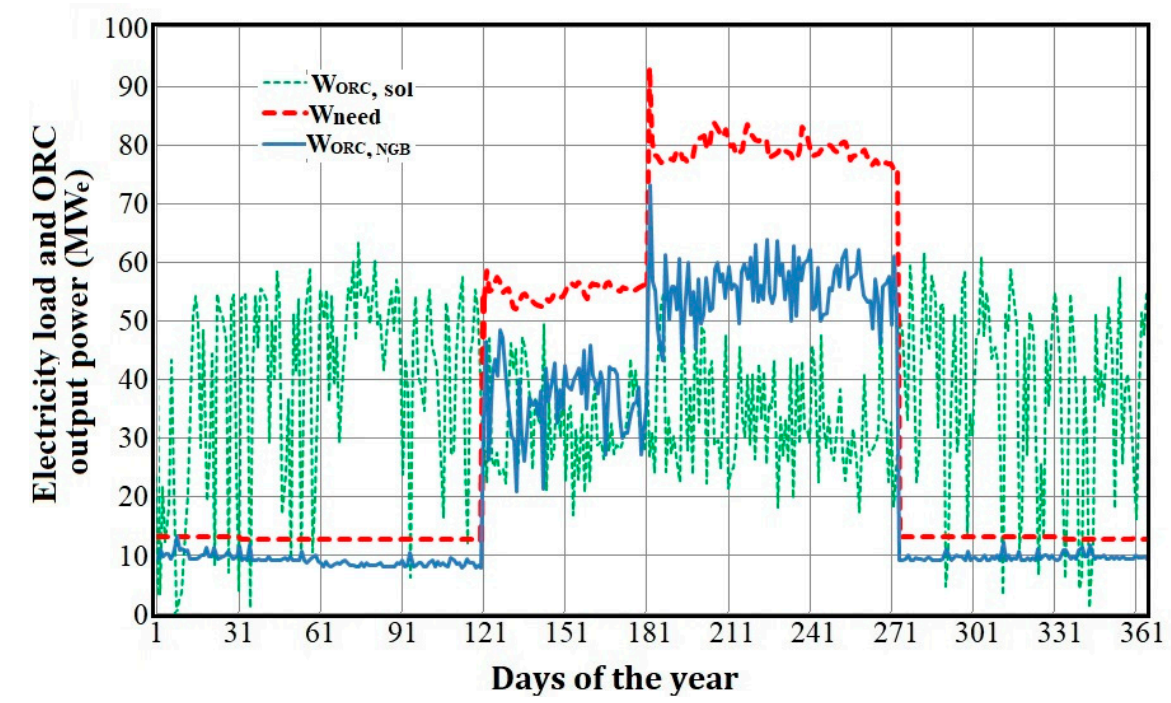

Figure 8. The daily electricity load and output power of the ORC. NLs $=9, \mathrm{SF}=32.20 \%, \mathrm{WF}=0.62 \%$.

Table 3. The heating energy cooling energy and electricity unit costs, Bandar-Abbas.

\begin{tabular}{|c|c|c|c|c|c|c|c|c|c|c|c|}
\hline $\begin{array}{c}\mathrm{LCH}_{\text {sol }} \\
\left.\left(\frac{\$}{\mathrm{kWh}}\right)_{\mathrm{t}}\right)\end{array}$ & $\begin{array}{c}\mathrm{LCH}_{\text {fuel }} \\
\left.\left(\frac{\$}{\mathrm{kWh}}\right)_{\mathrm{t}}\right)\end{array}$ & $\begin{array}{c}\mathrm{LCH} \\
\left(\frac{\mathrm{S}}{\mathrm{kWh}}\right)\end{array}$ & $\begin{array}{l}\mathrm{LCC}_{\text {sol }} \\
\left(\frac{\$}{\mathrm{kWh}}\right)\end{array}$ & $\begin{array}{l}\text { LCC }_{\text {fuel }} \\
\left(\frac{\$}{\mathrm{kWh}}\right)^{\prime}\end{array}$ & $\begin{array}{c}\mathrm{LCC} \\
\left(\frac{\mathrm{S}}{\mathrm{kWh}}\right)\end{array}$ & $\begin{array}{c}\mathrm{LCE}_{\text {sol }} \\
\left(\frac{\mathrm{s}}{\mathrm{kWh}}\right)\end{array}$ & $\begin{array}{l}\mathrm{LCE}_{\text {fuel }} \\
\left(\frac{\$}{\mathrm{kWh}}\right)\end{array}$ & $\begin{array}{c}\text { LCE } \\
\left(\frac{\$}{\mathrm{kWh}}\right)\end{array}$ & $\begin{array}{c}\mathrm{LCW}_{\text {sol }} \\
\left(\frac{\mathrm{s}}{\mathrm{m}^{3}}\right)\end{array}$ & $\begin{array}{c}\mathrm{LCW}_{\text {fuel }} \\
\left(\frac{\$}{\mathrm{~m}^{3}}\right)\end{array}$ & $\begin{array}{c}\text { LCW } \\
\left(\frac{\$}{\mathrm{~m}^{3}}\right)\end{array}$ \\
\hline 0.013 & 0.003 & 0.006 & 0.083 & 0.037 & 0.051 & 0.249 & 0.228 & 0.218 & 2.540 & 1.268 & 1.67 \\
\hline
\end{tabular}




\subsubsection{SPB}

SPB index is defined as the period of time during which the capital investment of a project is recovered (Equations (28-30)). This index was used to evaluate the economic performance of the two configurations of the study. Two main incentive strategies were considered in this work:

Electricity incentives (EI): incentives provided by the electricity incentive policy in Iran [63]. Based on the Iranian Ministry of Energy, the electricity generated from renewable sources is purchased at specific feed-in tariffs for 20 years. The incentive for the present case amounts to 4900 Iranian Rials $/ \mathrm{kWh}$. The mentioned incentive, which was issued in 2016 by SUNA, was equal to $0.153 \$ / \mathrm{kWh}$ for that time. However, during the period of two years, the value of Iranian currency has been dropped due to the sanctions that have imposed against the country. Therefore, the SUNA incentive at the present time is equal to $0.013 \$ / \mathrm{kWh}$.

Capital Subsidy (CS): It was assumed that $5-40 \%$ of the total capital cost of the system is paid to the developers by the government as a subsidy.

The calculations of the SPB were performed for both the solar-based system excluding the NGB and fuel prices $\left(\mathrm{SPB}_{\mathrm{sol}}\right)$ and the whole system including the $\mathrm{NGB}$ and fuel prices $\left(\mathrm{SPB}_{\mathrm{ave}}\right)$ and considering the products average units of costs (LCH, LCC, LCE, LCW). The results of the SPB analysis are shown in Figures 9 and 10 for the two incentive strategies. As can be seen from Figure 9, the current electricity incentive of $0.013 \$ / \mathrm{kWh}$ has no considerable effect on decreasing the SPB of the system. For the EI purchased cost of $0.15 \$ / \mathrm{kWh}$, the SPB of the solar based system is decreased from 13.89 years to 12.86 years. Even though the extra produced electricity would be purchased at the EI of $0.35 \$ / \mathrm{kWh}$, the SPB of the system would be decreased by $18.61 \%$ (or $13.31 \%$ ) and reaches 11.71 years (or 8.33 years) for the solar-based (or solar/fuel-based) system. This high SPB values are obtained due to the high capital costs of the LF solar field and ORC system. Therefore, the capital subsidy (CS) incentive scenario would be more favorable. As can be seen from Figure 10, the CS of $15 \%$ would result in decreasing the SPB by $17.61 \%$ (11.81 years); which is nearly equal to value that is obtained by considering the selling cost of $0.35 \$ / \mathrm{kWh}$ in the EI scenario. Figure 10 also shows that the SPB of the solar-based and solar/fuel-based system would be decreased to 10.42/7.47 years and 8.33/5.97 years, respectively, if $25 \% / 40 \%$ of the system total capital cost would be paid as the subsidy. In the other words, the SPB of the solar-based system would be decreased by $33 \% / 66 \%$ for the CS percentage of $25 \% / 40 \%$.

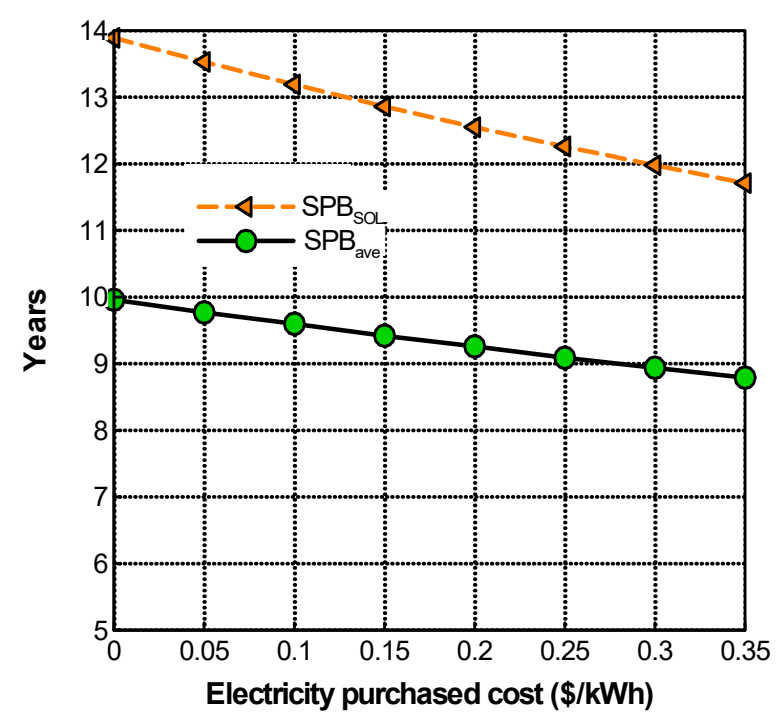

Figure 9. The Electricity Incentives (EI) scenario. 


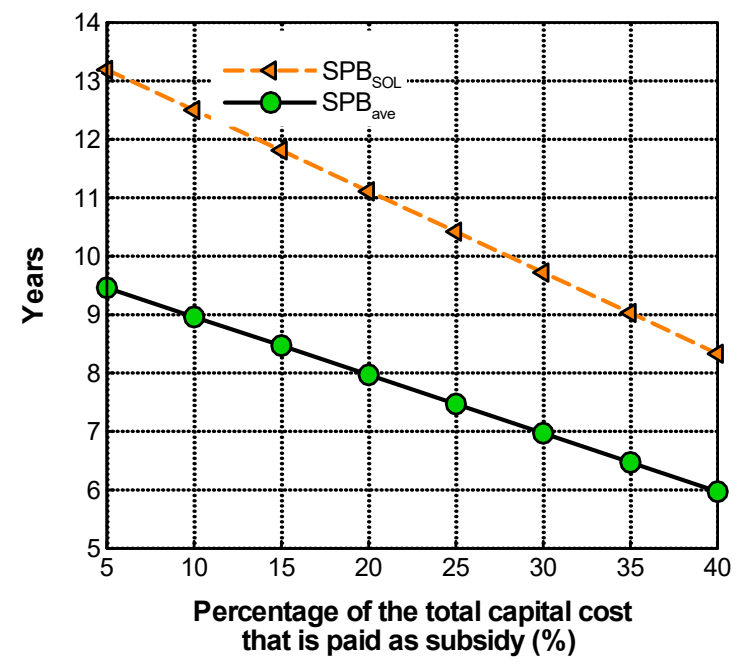

Figure 10. The Capital Subsidy (CS) scenario.

\subsubsection{Sensitivity Analysis}

A sensitivity analysis was performed to determine that to what extent the products' unit of costs are sensitive to different cost parameters of the system. Also, in order to specify the effect of solar radiation level on the numbers of solar field loops, and product units of costs, the hourly solar DNI data of four different coastal cities located in the Persian Gulf, Gulf of Oman and Gulf of Aden were applied in the calculations. Table 4 shows the cost parameters that were changed in the sensitivity analysis. Figure 11a shows the results of sensitivity analysis for unit cost of solar electricity $\left(\mathrm{LCE}_{\mathrm{sol}}\right)$ that is varied by the changing the LF and ORC capital costs. As is clear, the $\mathrm{LCE}_{\mathrm{sol}}$ is most sensitive to the ORC capital cost. The decreasing of the ORC (or LF) capital cost to $80 \%$ of its first assumption results in decreasing the $\mathrm{LCE}_{\mathrm{sol}}$ by $14.83 \%$ (or $7.61 \%$ ). Also, a $64 \%$ decrease in the ORC capital cost decreases the $\mathrm{LCE}_{\mathrm{sol}}$ by $27.43 \%(0.195 \$ / \mathrm{kWh})$. That part of the electricity that is produced on NGB (LCE fuel $)$ is dependent on the fuel cost and ORC capital cost. The results of the present paper showed that the $\mathrm{LCE}_{\text {fuel }}$ is considerably dependent on the ORC capital cost and the fuel price has a lower effect on the unit cost of the fuel-based electricity. The reduction of the ORC capital cost to $64 \%$ with respect to the initial assumption decreases the $\mathrm{LCE}_{\text {fuel }}$ from 0.226 to $0.156 \% \$ / \mathrm{kWh}$ (a decrease of $44.23 \%$ ). Also, if the fuel price subsidy in Iran were to decrease and the fuel price would increase from $0.03 \$ / \mathrm{m}^{3}$ to 7 -fold more $(0.21 \$ / \mathrm{kWh})$, the $\mathrm{LCE}_{\text {fuel }}$ would be increased by about $49.35 \%(0.338 \$ / \mathrm{kWh})$. The sensitivity of the average unit electricity cost (LCE), which is produced on $33.50 \%$ solar electricity and $66.50 \%$ of fuel, was also investigated. Figure 11b shows that the LCE is most sensitive to the ORC capital cost followed by LF capital cost and fuel price. The decrease of ORC and LF capital costs to $64 \%$ of their first cost assumption values results in a decrease of the LCE by about $37.33 \%$ and $4.77 \%$, respectively.

Table 4. Multiple values used to increase or decrease of the first cost assumptions that are shown in Table A3.

\begin{tabular}{|c|c|c|c|c|c|c|c|c|c|}
\hline \multicolumn{2}{|c|}{ Solar Field } & \multicolumn{2}{|c|}{ ORC } & \multicolumn{2}{|c|}{ Fuel } & \multicolumn{2}{|c|}{$\mathrm{ACH}$} & \multicolumn{2}{|c|}{ MED } \\
\hline $\operatorname{Cost}\left(\$ / \mathrm{m}^{2}\right)$ & Value & Cost $(\$ / k W)$ & Value & Cost $\left(\$ / \mathrm{m}^{3}\right)$ & Value & Cost $\left(\$ / k W_{c}\right)$ & Value & Cost $\left(\$ / \mathrm{m}^{3}\right)$ & Value \\
\hline 125 & 0.64 & 2000 & 0.57 & 0.03 & 1.00 & 262 & 0.72 & 1040 & 0.84 \\
\hline 135 & 0.69 & 2250 & 0.64 & 0.105 & 3.50 & 282 & 0.78 & 1140 & 0.92 \\
\hline 145 & 0.74 & 2500 & 0.71 & 0.21 & 7.00 & 302 & 0.83 & 1240 & 1.00 \\
\hline 155 & 0.79 & 2750 & 0.79 & - & - & 322 & 0.89 & 1340 & 1.08 \\
\hline 165 & 0.85 & 3000 & 0.86 & - & - & 342 & 0.94 & 1440 & 1.16 \\
\hline 175 & 0.90 & 3250 & 0.93 & - & - & 362 & 1.00 & 1540 & 1.24 \\
\hline 185 & 0.95 & 3500 & 1.00 & - & - & 382 & 1.06 & 1640 & 1.32 \\
\hline 195 & 1.00 & 3750 & 1.07 & - & - & 402 & 1.11 & 1740 & 1.40 \\
\hline 205 & 1.05 & 4000 & 1.14 & - & - & - & - & 1840 & 1.48 \\
\hline
\end{tabular}




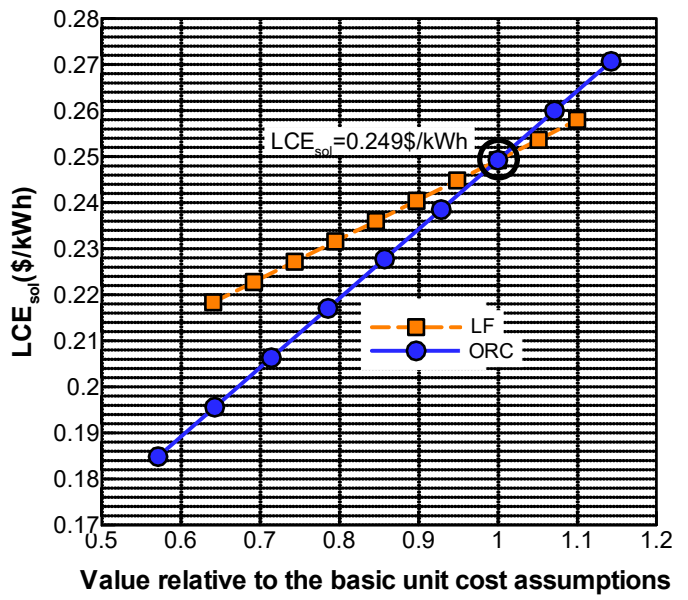

(a) $\mathrm{LCE}_{\mathrm{sol}}$

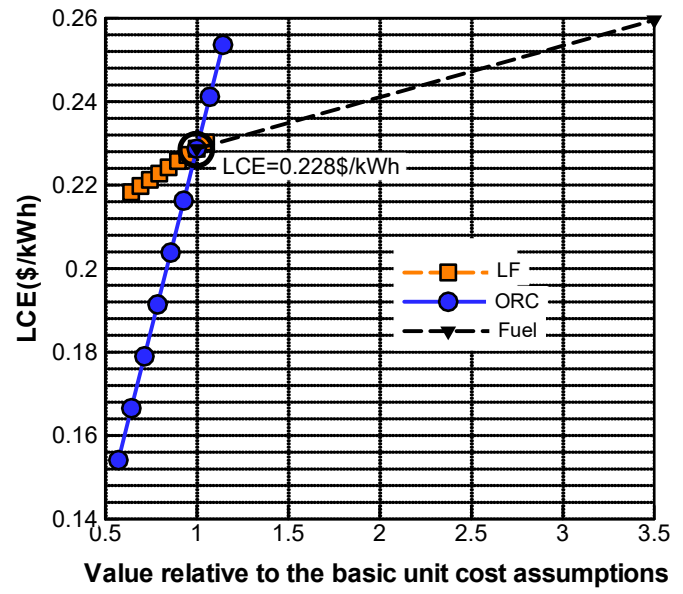

(b) LCE

Figure 11. the sensitivity of $\mathrm{LCE}_{\mathrm{sol}}$ and LCE to different cost parameters.

Figure 12a,b show the sensitivity analysis of the solar based and average (solar/fuel) fresh water unit cost $\left(\mathrm{LCW}_{\text {sol }}\right.$ and LCW). The $\mathrm{LCW}_{\text {sol }}$ is most sensitive to LF capital cost, and the MED and ORC capital costs are the second and third effective parameters, respectively (Figure 12a). For the average fresh water unit of cost however, the LCW is most sensitive to the MED capital cost and then LF capital cost, ORC capital cost and the fuel price. The results also reveal that by increasing of the fuel price from $0.03 \$ / \mathrm{m}^{3}$ to 7 -fold higher $\left(0.21 \$ / \mathrm{kWh}\right.$ ), the LCW would be increased to $2.69 \$ / \mathrm{m}^{3}$ (an increase of $60.31 \%$ ). At a marginal fuel price of $0.176 \$ / \mathrm{m}^{3}$, the $\mathrm{LCW}, \mathrm{LCW}_{\text {fuel }}$ and $\mathrm{LCW}_{\text {sol }}$ become identical and equal to $2.45 \$ / \mathrm{m}^{3}$.

The sensitivity analyses on $\mathrm{LCC}_{\text {sol }}$ and LCC are shown in Figure 13a,b. As can be seen, the $\mathrm{LCC}_{\text {sol }}$ is most sensitive to the ACH capital cost and then the LF capital cost. Decreasing the ACH capital cost to $72 \%$ of its capital cost results in decreasing the $\mathrm{LCC}_{\text {sol }}$ by about $31.47 \%\left(0.063 \$ / \mathrm{kWh}_{\mathrm{th}}\right)$. For the case of solar/fuel-based cooling energy unit of cost (LCC), the ACH capital cost, LF capital cost and fuel price, are first, second and third cost parameters that affect the LCC (Figure 13b). Under the global fuel price scenario $\left(0.21 \$ / \mathrm{m}^{3}\right)$, the LCC is increased to $0.061 \$ / \mathrm{kWh}_{\mathrm{th}}$ which is still lower than that is obtained for the solar-based system $\left(0.083 \$ / \mathrm{kWh}_{\mathrm{th}}\right)$.

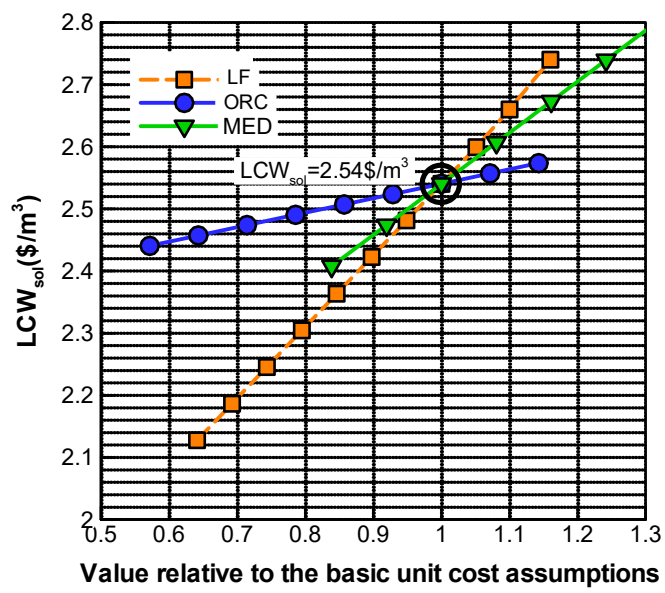

(a) $\mathrm{LCW}_{\text {sol }}$

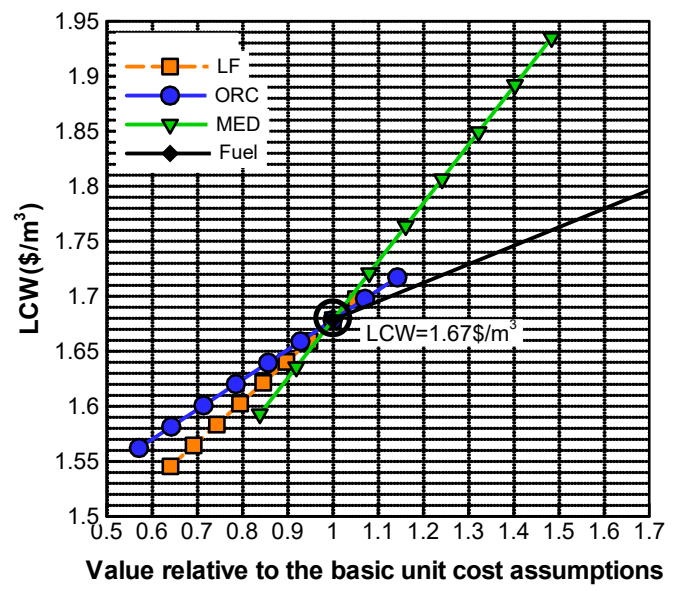

(b) LCW

Figure 12. the sensitivity of $\mathrm{LCW}_{\mathrm{sol}}$ and LCW to different cost parameters. 


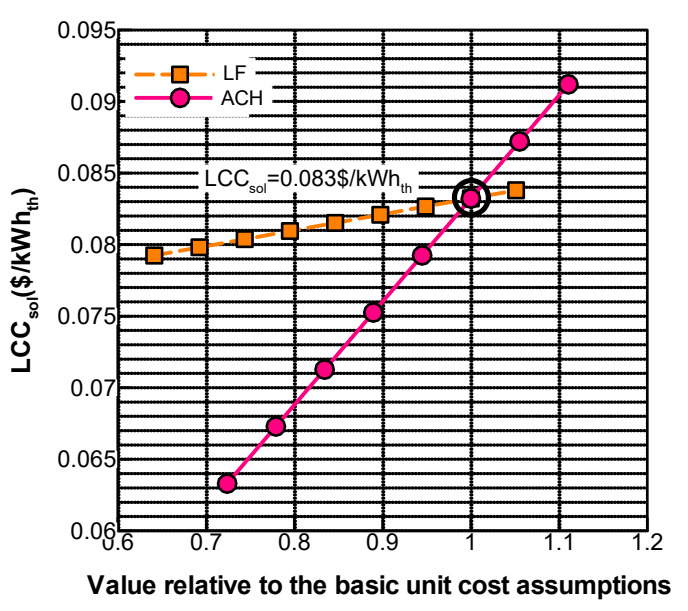

(a) the sensitivity analysis of $\mathrm{LCC}_{\text {sol }}$

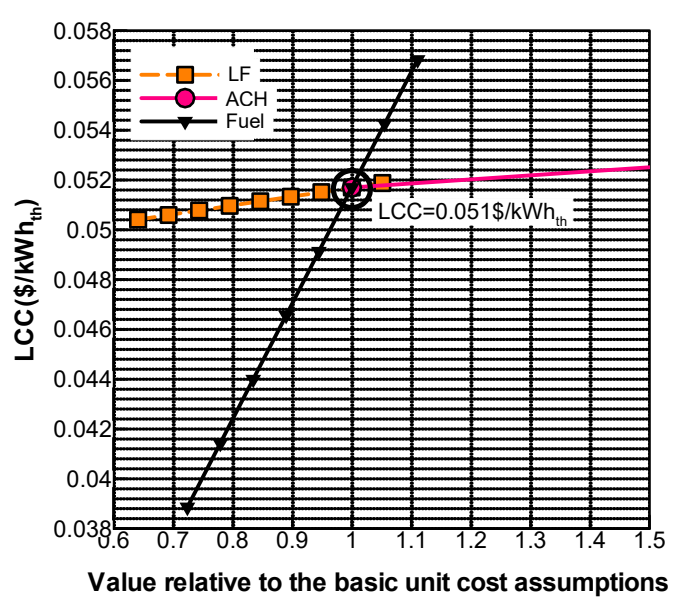

(b) the sensitivity analysis of LC

Figure 13. The sensitivity of $\mathrm{LCC}_{\mathrm{sol}}$ and LCC to different cost parameters.

In order to investigate the effect of solar radiation level on the unit costs of the products, the calculations were continued for three other locations with different DNI levels (1_Khormaksar, Yemen, 2_Masirah, Oman, 3_Bushehr, Iran). The average monthly daily DNI and GHI of four locations of the study are listed in Table 5. The results of the techno economic analysis of $\mathrm{LF}_{\mathrm{PS}}$ for four locations of the study are shown in Table 5.

As can be seen, the highest and lowest DNI is related to the Khormaksar $\left(1933 \mathrm{kWh} / \mathrm{m}^{2} / \mathrm{year}\right)$ and Bushehr ( $1350 \mathrm{kWh} / \mathrm{m}^{2} /$ year) locations, respectively. For each location, the proper solar field numbers of loops was determined so that the annual WF doesn't exceed 1\%. The annual SF was determined as $32.11 \%, 28.43 \%$ and $28.34 \%$ for Khormaksar, Masirah and Bushehr, respectively. As it is shown in Table 5, The lowest and highest $\mathrm{LCH}_{\text {sol }}, \mathrm{LCC}_{\text {sol }}, \mathrm{LCE}_{\text {sol }}$ and $\mathrm{LCW}_{\text {sol }}$ are related to the Khormaksar and Bushehr with respectively highest and lowest DNI among four locations.

The product unit costs for the two locations of Masirah and Bandar-Abbas are close because the nearly same DNI for both locations (the DNI of Masirah is 3.5\% higher than that of Bandar-Abbas). The $\mathrm{LCH}_{\text {sol }}$ and $\mathrm{LCE}_{\text {sol }}$ for Masirah is lower than that for Bandar-Abbas. However, $\mathrm{LCC}_{\text {sol }}$ for Bandar-Abbas is lower than for Masirah. In fact part of the $\mathrm{LCC}_{\text {sol }}$, which is related to the $\mathrm{LCH}_{\mathrm{sol}}$ $\left(\mathrm{LCH}_{\text {solar }} / \mathrm{COP}_{\mathrm{ACH}}\right.$, Appendix A Equation (5a)), for Bandar-Abbas is nearly 3.9\% higher than that of the Masirah. But, the other part of $\mathrm{LCH}_{\mathrm{Sol}}\left(\frac{\left[\mathrm{C}_{\mathrm{CAPEX}}(\mathrm{D})+\mathrm{C}_{\mathrm{CAPEX}}(\mathrm{ID})\right]_{\mathrm{ACH}}}{\mathrm{CP} \times(\mathrm{SF})}\right.$, Appendix A, Equation (5a)), which is associated with the fact the total annual cooling energy production (CP), for Bandar-Abbas is nearly $13.5 \%$ lower than that of the Masirah because of the higher percentage of annual SF in Bandar-Abbas as compared to Masirah. As consequence, the $\mathrm{LCC}_{\text {sol }}$ for Masirah is nearly $11.01 \%$ higher than that of the Bandar-Abbas. The same illustration can be used for the $\mathrm{LCW}_{\text {sol }}$ of the system for Masirah and Bandar-Abbas. Part of the fresh water unit of cost which is related to the electricity cost and thermal energy cost of the MED system for Masirah is lower than that of the Bandar-Abbas. However, the total annual fresh water production rate of Masirah with SF of $28.43 \%$ is lower than that of the Bandar-Abbas with SF of 32.20\%. Therefore, the $\mathrm{LCW}_{\text {sol }}$ for Masirah is $2.55 \%$ higher than that of Bandar-Abbas. The average solar/fuel based LCW is obtained as a value between $1.57 \$ / \mathrm{m}^{3}$ to $1.69 \$ / \mathrm{m}^{3}$ for four locations of the study. Table 5 also shows that for Khormaksar with the DNI level of $43.18 \%$ higher than that Bushehr, the $\mathrm{LCH}_{\text {sol }}$ and $\mathrm{LCE}_{\text {sol }}$ are obtained to be $44.00 \%$ and $28.09 \%$ lower than that are obtained for Bushehr. Also, the comparison between the unit product costs of Khormaksar and Bandar-Abbas with a nearly same annual SF percentage of $32 \%$ shows that because the DNI of Khormaksar is $32.21 \%$ higher than that of Bandar-Abbas, the $\mathrm{LCH}_{\text {sol }}, \mathrm{LCE}_{\mathrm{sol}}, \mathrm{LCC}_{\text {sol }}$ and $\mathrm{LCW}_{\text {sol }}$ for Khormaksar is respectively $33.00 \%, 24.78 \%, 3.09 \%$ and $14.82 \%$ lower than those for Bandar-Abbas. Also, at same annual SF of nearly $28 \%$ for Masirah and Bushehr, the DNI level for Masirah is $12.14 \%$ 
higher than that of Bushehr. As consequence, the $\mathrm{LCH}_{\mathrm{sol}}, \mathrm{LCE}_{\mathrm{sol}}, \mathrm{LCC}_{\mathrm{sol}}$ and $\mathrm{LCW}_{\mathrm{sol}}$ of Masirah are respectively $12.50 \%, 4.11 \%, 1.73 \%$ and $5.48 \%$ lower than those for Bushehr.

Table 5. Sensitivity analysis on the DNI solar radiation levels for four coastal cities.

\begin{tabular}{|c|c|c|c|c|}
\hline Parameter & Khormaksar & Masirah & Bandar-Abbas & Bushehr \\
\hline Latitude \& Longitude & $\begin{array}{l}12.81^{\circ} \mathrm{E} \\
45.03^{\circ} \mathrm{N}\end{array}$ & $\begin{array}{l}20.31^{\circ} \mathrm{E} \\
58.69^{\circ} \mathrm{N}\end{array}$ & $\begin{array}{l}26.53^{\circ} \mathrm{E} \\
53.96^{\circ} \mathrm{N}\end{array}$ & $\begin{array}{l}28.92^{\circ} \mathrm{E} \\
50.82^{\circ} \mathrm{N}\end{array}$ \\
\hline GHI (kWh/m²/year) & 2186 & 1879 & 1858 & 1718 \\
\hline DNI $\left(\mathrm{kWh} / \mathrm{m}^{2} /\right.$ year $)$ & 1933 & 1514 & 1462 & 1350 \\
\hline NGB rated capacity (MW) & 51.23 & 51.23 & 51.23 & 51.23 \\
\hline ORC rated power (MW) & 6.50 & 6.50 & 6.50 & 6.50 \\
\hline Natural gas price $\left(\$ / \mathrm{m}^{3}\right)$ & 0.03 & 0.03 & 0.03 & 0.03 \\
\hline ACH cooling capacity $\left(\mathrm{MW}_{\mathrm{t}}\right)$ & 7.5 & 7.5 & 7.5 & 7.5 \\
\hline MED capacity ( $\mathrm{m}^{3} /$ day) & 200 & 200 & 200 & 200 \\
\hline Project life time (years) & 25 & 25 & 25 & 25 \\
\hline LF mass flow rate $(\mathrm{kg} / \mathrm{s})$ & 25.73 & 25.73 & 25.73 & 25.73 \\
\hline LF output Temperature $\left({ }^{\circ} \mathrm{C}\right)$ & 185 & 185 & 185 & 185 \\
\hline DNI (kWh/m²/year) & 1933 & 1514 & 1462 & 1350 \\
\hline Solar field area $\left(\mathrm{km}^{2}\right)$ & 0.057 & 0.057 & 0.060 & 0.060 \\
\hline $\mathrm{SF}(\%)$ & 32.11 & 28.43 & 32.20 & 28.34 \\
\hline WF (\%) & 0.86 & 0.56 & 0.64 & 1.00 \\
\hline $\mathrm{LCH}_{\mathrm{sol}}\left(\$ / \mathrm{kWh}_{\mathrm{t}}\right)$ & 0.010 & 0.0128 & 0.0133 & 0.0144 \\
\hline $\mathrm{LCH}\left(\$ / \mathrm{kWh}_{\mathrm{t}}\right)$ & 0.0052 & 0.0057 & 0.0063 & 0.0062 \\
\hline $\mathrm{LCC}_{\text {sol }}\left(\$ / \mathrm{kWh}_{\mathrm{t}}\right)$ & 0.0807 & 0.0924 & 0.0832 & 0.0940 \\
\hline $\mathrm{LCC}\left(\$ / \mathrm{kWh}_{\mathrm{t}}\right)$ & 0.0508 & 0.0514 & 0.0517 & 0.0516 \\
\hline $\mathrm{LCE}_{\mathrm{sol}}\left(\$ / \mathrm{kWh}_{\mathrm{t}}\right)$ & 0.1997 & 0.2457 & 0.2492 & 0.2558 \\
\hline $\operatorname{LCE}\left(\$ / \mathrm{kWh}_{\mathrm{t}}\right)$ & 0.2168 & 0.2325 & 0.2186 & 0.2370 \\
\hline $\mathrm{LCW}_{\text {sol }}\left(\$ / \mathrm{kWh}_{\mathrm{t}}\right)$ & 2.212 & 2.605 & 2.540 & 2.748 \\
\hline $\operatorname{LCW}\left(\$ / \mathrm{kWh}_{\mathrm{t}}\right)$ & 1.578 & 1.643 & 1.678 & 1.685 \\
\hline Total fuel saving $\left(\times 10^{8} \mathrm{~m}^{3} / \mathrm{yr}\right)$ & 3.22 & 2.85 & 3.22 & 2.84 \\
\hline Total $\mathrm{CO}_{2}$ emissions $\left(\times 10^{3}\right.$ tons/yr) & 11.87 & 12.51 & 11.85 & 12.53 \\
\hline Total capital cost $(\mathrm{M} \$)$ & 38.97 & 38.97 & 40.57 & 40.57 \\
\hline
\end{tabular}

\subsection{Scenatrio\#2}

In scenario\#2, the required cooling energy, electricity and fresh water were considered to be supplied on the electricity that is generated by PV plant as it was mentioned formerly in the explanations of Figure 2. The DHW was assumed to be supplied on a small size NGB. The total electricity demand of the system includes the $\mathrm{CCH}$, RO pumps, lightening and appliances is shown in Figure 14. The application of a battery storage system is not consider in the present study due to huge difference between the amount of winter and summer electricity requirements. Part of the electricity load that does not meet by PV power plant was assumed to be purchased and supplied using the grid and the excess electricity that is produced by the PV plant was considered to be sold to the grid. 


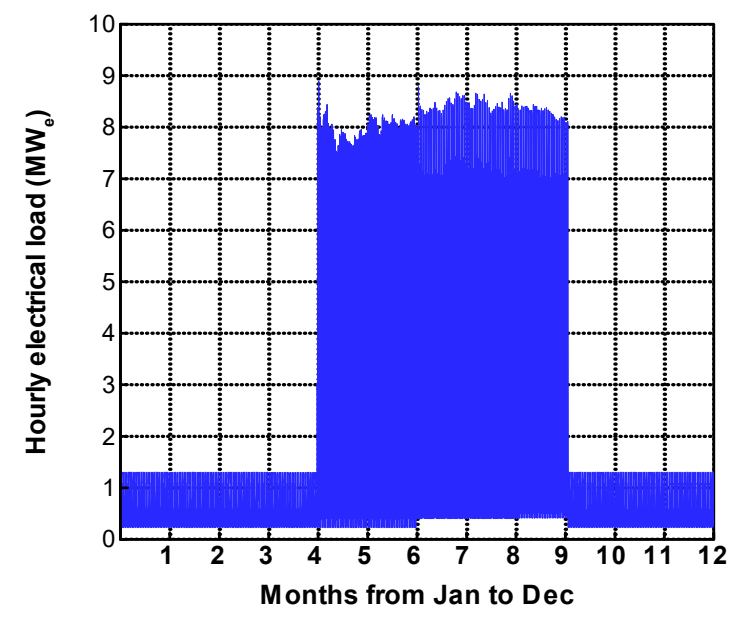

Figure 14. The required hourly electricity load of system, scenario\#2.

\subsubsection{PV Plant}

As was mentioned formerly in Section 4.6, the calculations of the PV output power were performed using the SAM software applying Equations (21-24). The PV module specifications that were used in the calculations are shown in Table 6. The amount of modules alongside of the PV strings was assumed to be 1 with the length of $1.66 \mathrm{~m}$ for each module. Like $\mathrm{LF}_{\mathrm{PS}}$, in the PV $\mathrm{PS}$ also, the calculations were performed for the four locations of Bandar-Abbas, Bushehr, Khormaksar, and Masirah. One axis tracking mode was considered for PV tilt angles during the yearly hours. The monthly optimum PV tilt angles for four regions of the study are shown in Table 6 . As can be seen from Table $6, \mathrm{~d}_{\text {opt }}$ was calculated for two scenarios of: (a) one module is mounted alongside the array, (b) two modules are mounted alongside the array. When two PV modules are mounted alongside the array, the height of $\left(h+h_{f}\right)$ is increased and as consequence, the row spacing between the PV arrays are increased. In the present work, the "one module" scenario was used in the calculations of the required land area for the PV plant and $d_{\text {opt }}$ was determined as $1.68 \mathrm{~m}, 2.21 \mathrm{~m}, 2.884 \mathrm{~m}$ and $3.24 \mathrm{~m}$ for Khormaksar, Masirah, Bandar-Abbas and Bushehr, respectively. For Khormaksar, Bandar-Abbas, Masirah and Bushehr, the land use factor of $\mathrm{F}$ was calculated to be equal to $83.49 \%, 41.17 \%, 57.52 \%$ and $34.70 \%$, respectively, if one PV module is mounted alongside the PV array.

Table 6. PV module specifications.

\begin{tabular}{cc}
\hline Parameter & Value \\
\hline Nominal efficiency & $15 \%$ \\
Max Power & $270.3 \mathrm{Wdc}$ \\
Module length/width & $1.66 \mathrm{~m} / 1 \mathrm{~m}$ \\
Max power voltage/Max power current & $31.8 \mathrm{Vdc} / 8.5 \mathrm{Adc}$ \\
Open Circuit Voltage/Short Circuit Current & $38.5 \mathrm{Vdc} / 9 \mathrm{Adc}$ \\
Temperature Coefficient of Power $\left(\alpha_{\mathrm{TP}}\right)$ & $-0.454 /{ }^{\circ} \mathrm{C}$ \\
Nameplate capacity of the plant & $6500 \mathrm{~kW}$ \\
Number of PV modules & 24,074 \\
Inverter Total capacity & $5416 \mathrm{~kW}$ \\
\hline
\end{tabular}

The results which include the LCC, LCE, LCW, total annual solar electricity generation, total PV area, required land area, total capital cost and field efficiency are shown in Table 7. The results tabulated in Table 7 show that in order to have the same total annual electricity production rate for the system under two scenarios, the nominal power of the PV plant should be nearly $12.78 \%, 8.80 \%, 5.15 \%$ and $17.06 \%$ higher than the ORC nominal power, for the four regions of Khormaksar, Bandar-Abbas, Masirah and Bushehr, respectively. The LCE, LCW and LCC of PV PS is lower than that of LFPS for the 
four locations. The LCE of $\mathrm{PV}_{\mathrm{PS}}$ for Khormaksar, Bandar-Abbas, Masirah and Bushehr are respectively $40.04 \%, 47.45 \%, 50.73 \%$ and $41.32 \%$ lower than that of the $\mathrm{LF}_{\mathrm{PS}}$ at these locations. The LCW of the $\mathrm{PV}_{\mathrm{PS}}$ plant is nearly $49.15 \%$ to $57.89 \%$ lower than that of the other plant with minimum and maximum differences for Bushehr and Khormaksar, respectively. Also, the LCC of $\mathrm{LF}_{\mathrm{PS}}$ is nearly $45 \%$ higher than that of the other plant due to the low unit cost of thermal energy that is used in the $\mathrm{ACH}$ of the former plant (ranges from $0.010 \$ / \mathrm{kWh}_{\mathrm{t}}$ to $0.014 \$ / \mathrm{kWh}_{\mathrm{t}}$, Table 6). For Khormaksar with low latitude angle of $12.81^{\circ} \mathrm{E}$, the total required land area of $\mathrm{PV}_{\mathrm{ps}}$ is nearly $25.07 \%$ lower than that of $\mathrm{LF}_{\mathrm{ps}}$. However, for Masirah, Bandar-Abbas and Bushehr the $\mathrm{PV}_{\mathrm{ps}}$ required land area are respectively $1.52 \%, 30.43 \%$, and $66.50 \%$ higher than the $\mathrm{LF}_{\mathrm{ps}}$ required land area. For all locations, the $\eta_{\mathrm{se}}$ of $\mathrm{PV}_{\mathrm{PS}}$ is higher than the other plant. The results of solar to electric efficiency of the field $\left(\eta_{\mathrm{se}}\right)$ is differ from those reported in the previous research studies in which the $\eta_{\text {se }}$ of the PTC/Rankine cycle is higher than the PV plant with same nominal capacity $[44,45]$. The reason is that the thermal efficiency of the Rankine cycle is considerably higher than the ORC. Besides, the PTC solar to electricity efficiency is higher than that the LF solar field. Therefore, $\eta_{\mathrm{se}}$ of $\mathrm{LF}_{\mathrm{PS}}$ for Khormaskar, Bandar-Abbas, Masirah and Bushehr is respectively $4.76 \%, 8.53 \%, 2.18 \%$ and $0.81 \%$ is lower than that of PVPS. The CUF of LFPS for three locations of Bandar-Abbas, Masirah and Bushehr are the same and equal to $23 \%$. For Khormaskar, however, the CUF of LFPS was obtained as $25 \%$ due to its higher GHI level. The PVPS CUF is lower than that of the $\mathrm{LF}_{\mathrm{PS}} ; 14.28 \%, 9.52 \%, 4.76 \%$ and $8.69 \%$ for Bushehr, Bandar-Abbas, Msirah and khosmaksar, respectively. A comparison between the PTC/SRC and PV plant reported in the previous works shown that the CUF of the PTC/SRC is nearly $37.5 \%$ to $50.2 \%$ higher than that of the PV plant depending on the DNI and GHI solar radiation levels [45]. Because of the low efficiency of the ORC and LF as compared of the SRC and PTC, the difference between the CUF of the $\mathrm{LF}_{\mathrm{PS}}$ and $\mathrm{PV}_{\mathrm{PS}}$ is lower than that of the PTC/SRC and PV plants. The results shown in Table 7 are related to the comparison of two scenarios when the same total annual electricity generation is considered for both systems. Table 7 also shows the IRRs of two configurations for all locations of the study. As it is clear, the IRR of PVPS changes from $13.36 \%$ to $13.39 \%$ which is slightly higher than that of $\mathrm{LF}_{\mathrm{PS}}$ that changes from $13.01 \%$ to $13.13 \%$.

The daily solar electricity productions of both multi-generation plants are shown in Figure 15 for Bandar-Abbas with annual SF of $32.20 \%$. As it was expected, the amount of excess electricity that can be sold to the grid for the cold and mild months is higher than that of the warm season for both systems. The electricity generation of $\mathrm{LF}_{\mathrm{PS}}$, which benefits the hourly DNI of the region, during the winter is higher than that of $\mathrm{PV}_{\mathrm{PS}}$. However, the electricity generation rates of both systems tolerance between same ranges of $20 \mathrm{MWh}$ to $50 \mathrm{MWh}$ per day during the warm months.

Table 7. The comparison between the two scenarios with same SFs.

\begin{tabular}{|c|c|c|c|c|c|c|c|c|}
\hline Location & \multicolumn{2}{|c|}{ Khormaksar } & \multicolumn{2}{|c|}{ Masirah } & \multicolumn{2}{|c|}{ Bandar-Abbas } & \multicolumn{2}{|c|}{ Bushehr } \\
\hline $\mathrm{SF}(\%)$ & \multicolumn{2}{|c|}{32.11} & \multicolumn{2}{|c|}{28.43} & \multicolumn{2}{|c|}{32.20} & \multicolumn{2}{|c|}{28.34} \\
\hline Scenario & $\mathrm{LF}_{\mathrm{PS}}$ & $\mathrm{PV}_{\mathrm{PS}}$ & $\mathrm{LF}_{\mathrm{PS}}$ & $P V_{P S}$ & $\mathrm{LF}_{\mathrm{PS}}$ & $\mathrm{PV}_{\mathrm{PS}}$ & $\mathrm{LF}_{\mathrm{PS}}$ & $\mathrm{PV}_{\mathrm{PS}}$ \\
\hline PV/ORC (MW) & 6.500 & 7.331 & 6.500 & 6.853 & 6.500 & 7.074 & 6.500 & 7.609 \\
\hline $\mathrm{LCE}_{\mathrm{sol}}\left(\$ / \mathrm{kWh}_{\mathrm{t}}\right)$ & 0.1997 & 0.1426 & 0.2457 & 0.163 & 0.2492 & 0.169 & 0.2558 & 0.181 \\
\hline $\mathrm{LCW}_{\text {sol }}\left(\$ / \mathrm{kWh}_{\mathrm{t}}\right)$ & 2.212 & 1.484 & 2.605 & 1.645 & 2.540 & 1.588 & 2.748 & 1.718 \\
\hline $\mathrm{LCC}_{\mathrm{sol}}\left(\$ / \mathrm{kWh}_{\mathrm{t}}\right)$ & 0.0807 & 0.1175 & 0.0924 & 0.1335 & 0.0832 & 0.1261 & 0.0940 & 0.1396 \\
\hline Solar electricity (GWh/yr) & 14.517 & 14.517 & 11.831 & 11.831 & 11.812 & 11.812 & 11.862 & 11.862 \\
\hline LF mirror or PV area (ha) & 5.34 & 4.51 & 5.34 & 4.21 & 6.00 & 4.35 & 6.00 & 4.68 \\
\hline Total solar field land area (ha) & 7.20 & 5.40 & 7.20 & 9.05 & 8.10 & 10.56 & 8.10 & 13.56 \\
\hline $\mathrm{F}(\%)$ & 74.07 & 83.49 & 74.07 & 57.52 & 74.07 & 41.17 & 74.07 & 34.70 \\
\hline CUF & 0.25 & 0.23 & 0.21 & 0.20 & 0.21 & 0.19 & 0.21 & 0.18 \\
\hline$\eta_{\mathrm{se}}(\%)$ & 14.06 & 14.73 & 14.63 & 14.95 & 13.47 & 14.62 & 14.64 & 14.76 \\
\hline $\operatorname{IRR}(\%)$ & 13.05 & 13.39 & 13.09 & 13.36 & 13.01 & 13.38 & 13.11 & 13.37 \\
\hline Total capital cost $(\mathrm{M} \$)$ & 38.97 & 27.39 & 38.97 & 25.81 & 40.57 & 26.54 & 40.57 & 28.30 \\
\hline
\end{tabular}




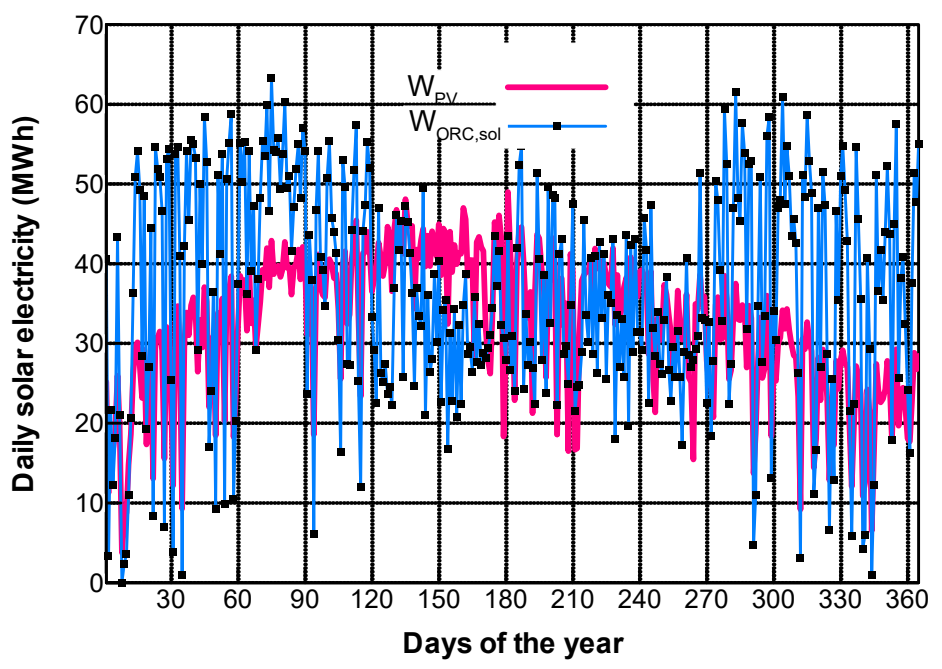

Figure 15. The daily solar electricity generated by the $\mathrm{PV}_{\mathrm{PS}}(7074 \mathrm{~kW})$ and $\mathrm{LF}_{\mathrm{PS}}(6500 \mathrm{~kW})$ systems for Bandar-Abbas with SF $=32.20 \%$.

The sensitivity analysis for three cost parameters of $\mathrm{PV}, \mathrm{CCH}$ and $\mathrm{RO}$ capital cost was performed in order to determine that the LCE of the system is most sensitive to which component. In order to compare the LCE of both plants, the sensitivity of the $\mathrm{LCE}_{\mathrm{sol}} \mathrm{S}$ of $\mathrm{LF}_{\mathrm{PS}}$ and $\mathrm{PV}_{\mathrm{PS}}$ to the relative parameters are shown in a same figure (Figure 16a). It is clear from Figure 16a that the LCE of LFPS can be decreased to the LCE of the PV plant only if the LF capital cost were decreased from $195 \$ / \mathrm{m}^{2}$ to $53 \$ / \mathrm{m}^{2}$ (367\% decrease). Also, at the LF solar field of $195 \$ / \mathrm{m}^{2}$, the LCE of $\mathrm{LF}_{\mathrm{PS}}$ is equal to that of PV plant by decreasing the ORC capital cost from $3500 \$ / \mathrm{kW}_{\text {nominal }}$ to $1950 \$ / \mathrm{kW}_{\text {nominal }}(179 \%$ decrease). The sensitivity of the LCC to the PV and CCH is shown in Figure 16b. As can be seen, the LCC is most sensitive to PV capital cost. In order to have an equal LCC for both polygeneration systems, the capital cost of PV modules should be decreased from $3300 \$ / \mathrm{kW}$ to $580 \$ / \mathrm{kW}$ (a $568 \%$ decrease). As it was mentioned formerly, the high unit cost value of electricity in $\mathrm{PV}_{\mathrm{PS}}$ causes the LCC of CCH in this plant becomes higher than that of the other plant with a low unit cost of heat $(\mathrm{LCH})$ that is consumed in the ACH. The sensitivity analysis of the LCW in Figure 16c shows that the PV and RO capital costs have similar effect on the unit cost of fresh water in the $\mathrm{PV}_{\mathrm{PS}} ; 63 \%$ decrease in the capital cost of $\mathrm{PV}$ or $\mathrm{RO}$ results in $14.28 \%$ decrease in the LCW of the system. The LCW of the LFPS system is considerably higher than that of the other plant because of the higher electricity and thermal energy costs that is used in the MED unit. Only when the LF solar field capital cost would be decreased from $195 \$ / \mathrm{m}^{2}$ to $46 \$ / \mathrm{m}^{2}$, the LCW of both plants would be equal. 


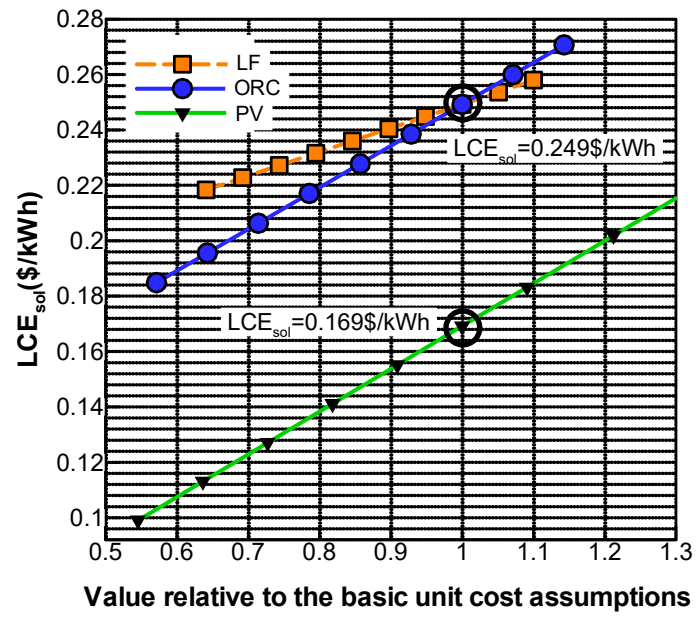

(a) LCE

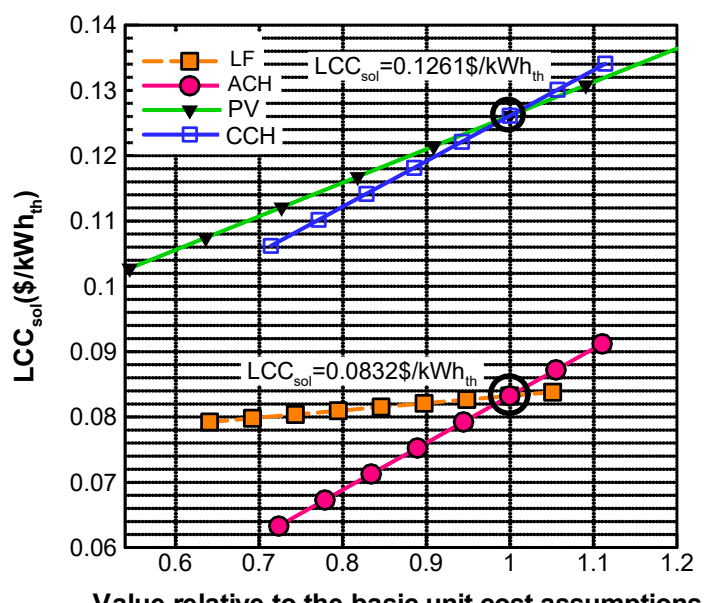

(b) LCC

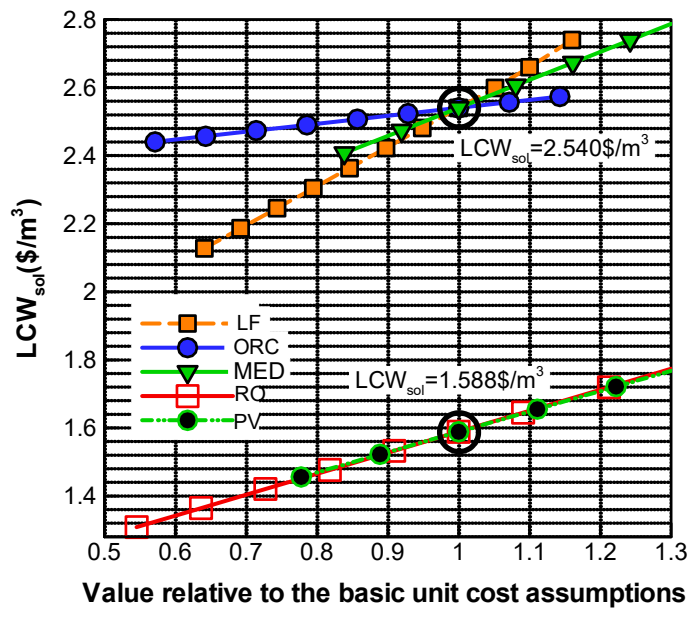

(c) LCW

Figure 16. The sensitivity of LCE, LCC and LCW to different cost parameters for two system layouts. 


\subsubsection{SPB of Scenario\#2}

In order to have a fair comparison of the payback period of the two multi-generation system, for two EI and CS incentive scenarios the SPB of the PVPS was calculated based on two different cases: (a) the electricity and fresh water produced by $\mathrm{PV}_{\mathrm{PS}}$ are sold to the users at the system fixed price, (b) the electricity and fresh water produced by $\mathrm{PV}_{\mathrm{PS}}$ are sold to the user with the unit costs that are obtained for LFPS. The results of SBP time are shown in Figure 17a,b for the EI and CS incentive

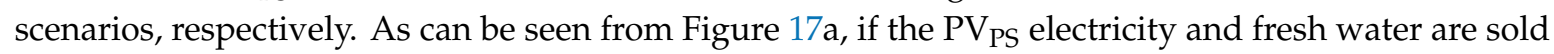
at the final unit costs obtained for this system, the total investment will be returned back to the investor after 13.65 years if no electricity incentive would be assigned to the system. If the excess electricity of the system is sold to the grid at the unit cost of $0.20 \$ / \mathrm{kWh}$ (or $0.35 \$ / \mathrm{kWh}$ ), the capital investment can be returned back at the nearly 12 years (or 11 years). If the electricity and fresh water of PV $V_{P S}$ are sold to the users at $\mathrm{LF}_{\mathrm{PS}}$ unit of costs $\left(\mathrm{LCE}=0.249 \$ / \mathrm{kWh}, 2.540 \$ / \mathrm{m}^{3}\right)$, the capital investment will be returned back during 10 years, 8.8 years and 8 years for the EI scenarios with electricity selling cost of $0 \$ / \mathrm{kWh}, 0.2 \$ / \mathrm{kWh}$ and $0.35 \$ / \mathrm{kWh}$, respectively. This means that without any incentive, the SPB time of $\mathrm{PV}_{\mathrm{PS}}$ is nearly $31.5 \%$ higher than that of LFPS (14.6 years, Figure 12). Similarly, for the CS scenario (Figure 17b), if the products are sold to users at PV PS units of costs and 5\% (or 40\%) of the total capital cost would be paid by the government; the payback time of the system would be 13 years (or 8 years). For the case when the electricity and fresh water of $\mathrm{PV}_{\mathrm{PS}}$ are sold to the users at the unit costs of $\mathrm{LF}_{\mathrm{PS}}$, the SPB of PV $\mathrm{PS}$ will be 9.4 years and 6 years for the CS incentives of $5 \%$ and $40 \%$, respectively. At such case, for $5 \% / 40 \%$ of CS incentives, the SPB of the PV/RO system (9.4 years/6 years) is nearly $48.93 \% / 46.66 \%$ lower than that of the $\mathrm{LF}_{\mathrm{PS}}$ (14 years/8.8 years, Figure 13 ).

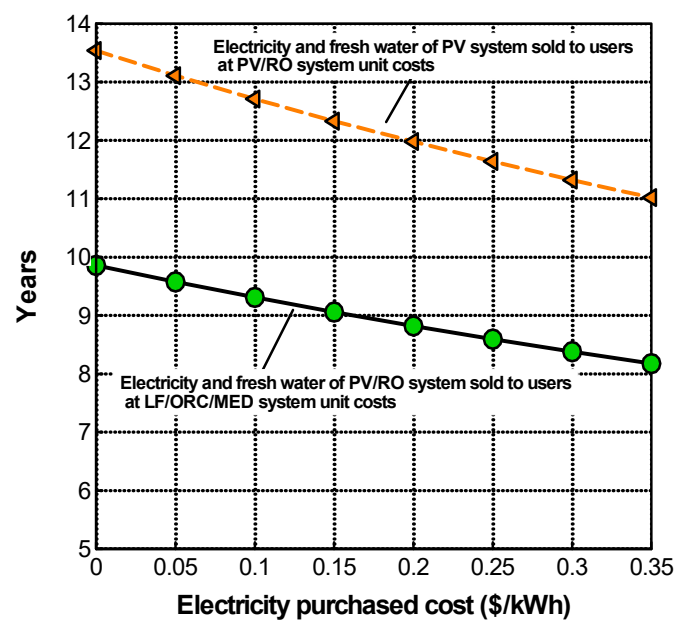

(a) Electricity Incentives (EI)

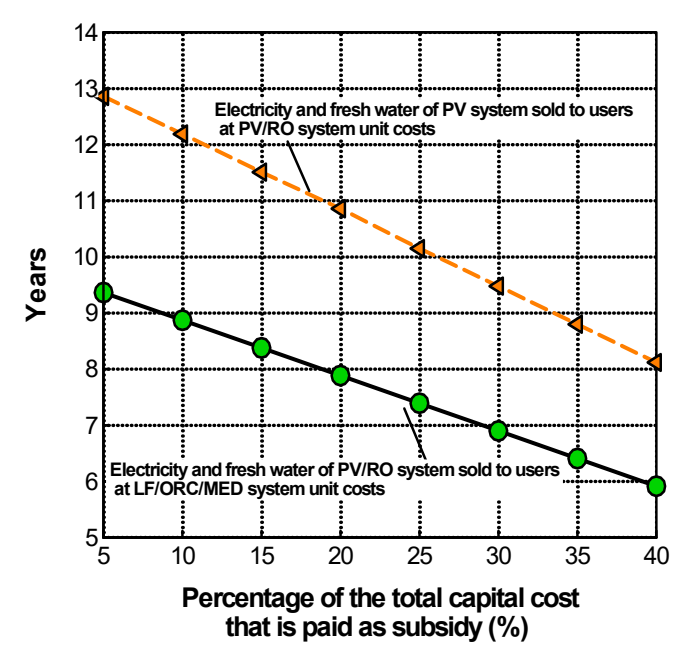

(b) Capital Subsidy (CS)

Figure 17. The SPB time for $P V_{P S}$ under $E I$ and $C S$ incentive scenarios.

\subsection{The Cumulative Electricity Generation}

The total electricity production during the lifetime of the system for Bandar-Abbas was also determined for both multi-generation systems. The annual performance degradation of the PV and LF were considered as $0.5 \%$ and $0.2 \%$, respectively. Figure 18 shows the cumulative energy productions of both systems over 25 years of their lifetime. As can be seen, LF Ps produces 355 GWh as compared to $\mathrm{PV}_{\mathrm{PS}}$ with total electricity production of $255 \mathrm{GWh}$. 


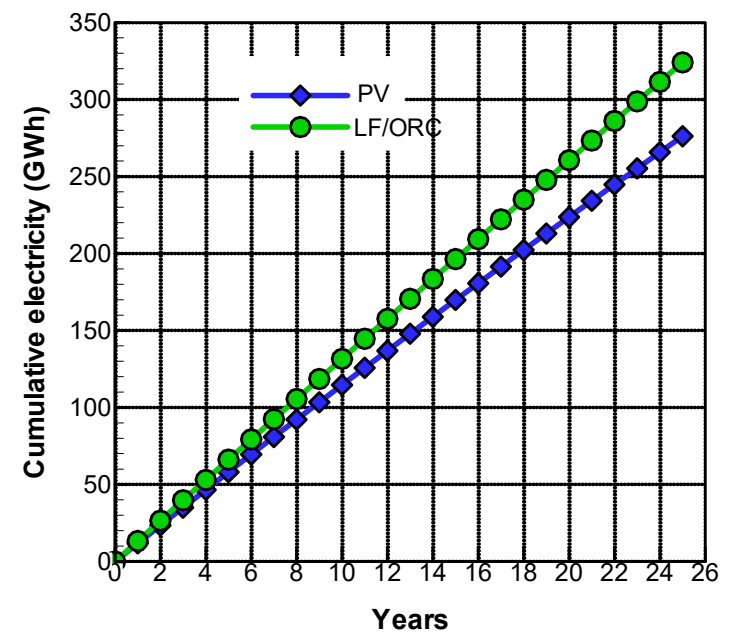

Figure 18. Cumulative electricity produced by $\mathrm{LF}_{\mathrm{PS}}$ and $\mathrm{PV} \mathrm{V}_{\mathrm{PS}}$.

\section{Conclusions}

A comprehensive techno-economic comparison between two different solar polygeneration systems ( $\mathrm{LF}_{\mathrm{PS}}(\mathrm{LF} / \mathrm{ORC} / \mathrm{ACH} / \mathrm{MED})$, and $\mathrm{PV}_{\mathrm{PS}}(\mathrm{PV} / \mathrm{CCH} / \mathrm{RO})$ ) was performed. Both systems were designed to meet the same annual electricity, space cooling and fresh water requirements for four regions with hot and humid climates. For each location, the electricity unit cost, cooling energy unit cost, fresh water unit cost, the annual solar electricity production, land use factor (F) capacity utilization factor (CUF), the simple payback time of the systems (SPB), and the solar to electric efficiency $\left(\eta_{\mathrm{se}}\right)$ of two plants were compared for the same total annual solar electricity generation rate. The following outcomes were derived from the study:

The application of $\mathrm{LF}_{\mathrm{PS}}$ system with SF of $32.20 \%$ would result in annual fuel savings of 3228.26 million $\mathrm{m}^{3} /$ year and $\mathrm{CO}_{2}$ emission reduction of 11,850 tonnes/year.

If the same nominal capacity of $6500 \mathrm{~kW}$ was considered in the calculations of both systems, the total annual electricity generation and capital investment of $\mathrm{PV}_{\mathrm{PS}}$ became $8.84 \%$ and $64.65 \%$, respectively, lower than those of $\mathrm{LF}_{\mathrm{PS}}$. Therefore, the total annual solar electricity generation of $\mathrm{PV}_{\mathrm{PS}}$ is decreased by $8.84 \%$ and this causes to increase the $\mathrm{LCC}_{\text {sol }}$ and $\mathrm{LCW}_{\text {sol }}$ of the system.

The sensitivity analysis on the solar radiation level of four different locations revealed that for Khormaksar and Bushehr with maximum and minimum GHI/DNI levels (2186/1933 kWh/m²/year and $1718 / 1350 \mathrm{kWh} / \mathrm{m}^{2} /$ year), respectively, the $\mathrm{LCE}_{\mathrm{sol}}, \mathrm{LCW}_{\mathrm{sol}}$ and $\mathrm{LCC}_{\mathrm{sol}}$ of the $\mathrm{LF}_{\mathrm{PS}}$ system for Khormaksar are respectively $28.09 \%, 24.03 \%$ and $16.48 \%$ lower than that for Bushehr. Also, these values for the $\mathrm{PV}_{\mathrm{PS}}$ in Khormaksar are respectively, $26.92 \%, 15.76 \%$ and $18.80 \%$ lower than those in Bushehr.

For Khormaksar, Bandar-Abbas, Masiraha and Bushehr, the solar to electricity efficiency of LF $_{\mathrm{PS}}$ are respectively, $4.76 \%, 8.53 \%, 2.18 \%$ and $0.82 \%$ higher than those of the other scenario for the same annual electricity production rate.

If same annual electricity generation is considered for both polygenearion systems, the SPB of $\mathrm{LF}_{\mathrm{PS}}$ and $\mathrm{PV}_{\mathrm{PS}}$ systems are obtained as 13.97 years and 13.54 years, respectively, if no incentive is considered for the electricity sale. The capital incentive (CI) scenario was shown to be more favorable than the electricity incentive scenario (EI). If the electricity would be purchased by the government at the LCE price of $0.20 \$ / \mathrm{kWh}(\mathrm{EI})$, the SPB time of the $\mathrm{LF}_{\mathrm{PS}}$ and $\mathrm{PV}$ PS are decreased to 12.5 years and 12 years, respectively. However, under the CI scenario, if $30 \%$ of the capital investment of the system would be paid as the subsidy by the government, the SPB of $L_{\mathrm{PS}}$ and $\mathrm{PV}_{\mathrm{PS}}$ are decreased to 9.8 years and 9.4 years, respectively. 
The cumulative electricity generation of the $\mathrm{LF}_{\mathrm{PS}}$ will be $39.21 \%$ higher than that of the PV system over the 25 years of the project due to the higher annual performance degradation of the PV modules as compared to the LFPS.

The IRR of PV $\mathrm{PS}$ (13.36-13.39\%) which is slightly higher than that of $\mathrm{LF}_{\mathrm{PS}}(13.01-13.13 \%)$ for four locations of the study.

Author Contributions: All authors contributed to this work. In particular, I.B.A. mainly focused on the LF solar field, PV and MED subsystem developing energetic and economic models. F.C. developed the overall dynamic simulation model. M.V. developed the ORC and chiller models. All authors revised and approved the manuscript.

Funding: This research was funded by University of Zabol, deputy for the research and technology, under the Grant code of UOZ-GR-9517-89.

Conflicts of Interest: The authors declare no conflict of interest.

\section{Nomenclature}

\begin{tabular}{|c|c|}
\hline $\mathrm{ACH}$ & Absorption Chiller \\
\hline$A_{\text {field }}$ & Solar field aperture area $\left(\mathrm{m}^{2}\right)$ \\
\hline $\mathrm{A}_{\mathrm{sf}}$ & LF mirrors aperture area or PV surface area \\
\hline Aland & Total required land area for the solar field \\
\hline $\mathrm{A}_{\mathrm{PV}}$ & PV module area $\left(\mathrm{m}^{2}\right)$ \\
\hline $\mathrm{C}_{\text {CAPEX }}(\mathrm{D})$ & Capital annualized direct costs, $\$$ \\
\hline C CAPEX $_{\text {(ID) }}$ & Capital annualized indirect costs, \$ \\
\hline Battery & Bat \\
\hline $\mathrm{CCH}$ & Compression Chiller \\
\hline $\mathrm{CHP}$ & Combined Heat and Power \\
\hline $\mathrm{C}_{\mathrm{el}}$ & Electricity costs, $\$$ \\
\hline $\mathrm{C}_{\mathrm{f}}$ & Fuel costs, $\$$ \\
\hline $\mathrm{C}_{\text {Ins }}$ & Insurance costs, $\$$ \\
\hline $\mathrm{C}_{\mathrm{L}}$ & Labor costs, $\$$ \\
\hline $\mathrm{COP}$ & Coefficient of performance \\
\hline $\mathrm{CP}$ & Annual cooling production \\
\hline CPC & Compound Parabolic Concentrator \\
\hline CPVT & Concentrated Photovoltaic/Thermal \\
\hline CRF & Capital recovery factor \\
\hline $\mathrm{C}_{\mathrm{SP}}$ & Spare parts replacement costs, $\$$ \\
\hline CSP & Concentrating solar power plant \\
\hline CUF & Capacity Utilization Factors \\
\hline DNI & Direct Normal Irradiation, $\left(\mathrm{W} / \mathrm{m}^{2}\right)$ \\
\hline DHW & Domestic Hot Water \\
\hline EG & Annual electricity production \\
\hline ETC & Evacuated flat plate solar Collector \\
\hline $\mathrm{E}_{\mathrm{el}}$ & total electricity that is generated by solar (LF/ORC or PV) \\
\hline $\mathrm{E}_{\mathrm{sol}}$ & total available solar energy on the solar field \\
\hline $\mathrm{F}_{\mathrm{T}, \text { corr }}$ & Temperature correction factor \\
\hline GHI & Global Horizontal Irradiance \\
\hline GOR & Gain Output Ratio \\
\hline $\mathrm{HE}$ & Heat exchanger \\
\hline $\mathrm{h}_{\text {out }, \mathrm{SF}}$ & Enthalpy of the steam at the outlet of the solar field \\
\hline $\mathrm{HP}$ & Annual heating production \\
\hline $\mathrm{HV}_{\mathrm{NG}}$ & Natural gas heating value \\
\hline HTF & Heat Transfer Fluid \\
\hline $\mathrm{i}$ & Interest rate $(\%)$ \\
\hline $\mathrm{IAM}_{\mathrm{t}}$ & Transversal incident angle modifier \\
\hline IAM $_{L}$ & Longitudinal incident angle modifier \\
\hline IEA & International Energy Agency \\
\hline
\end{tabular}


$\mathrm{I}_{\mathrm{O}} \quad$ Reference total incident radiation, $1000 \mathrm{~W} / \mathrm{m}^{2}$

$\mathrm{I}_{\mathrm{t}} \quad$ Total incident global radiation $\left(\mathrm{W} / \mathrm{m}^{2}\right)$

$\mathrm{L} \quad$ Receiver length, $\mathrm{m}$

LCE Levelised cost of electricity, $\$ / \mathrm{kWh}$

LCC Levelised cost of cooling energy, $\$ / \mathrm{kWh}_{\mathrm{t}}$

$\mathrm{LCH} \quad$ Levelised cost of heating energy, $\$ / \mathrm{kWh}_{\mathrm{t}}$

LCW Levelised cost of water, $\$ / \mathrm{m}^{3}$

$\mathrm{L}_{\mathrm{f}} \quad$ Focal distance, $\mathrm{m}$

LF Linear Fresnel solar field

LF $\quad$ LF/ORC/ACH/MED configuration

$\mathrm{m}_{\mathrm{NG}} \quad$ Natural gas mass

$\dot{\mathrm{m}}_{\mathrm{D}} \quad$ Fresh water flow rate

$\dot{\mathrm{m}}_{\mathrm{SF}} \quad$ Motive steam mass flow rate

$\dot{\mathrm{m}}_{\mathrm{SF}}$ Mass flow rate that is flowed through the ORC heat exchanger

ME Middle East

MED Multi Effect desalination

$\mathrm{N} \quad$ Number of project Life time

NGB Natural gas boiler

NREL Natural Renewable Energy Laboratory

ORC Organic Rankine Cycle

PEMFC Proton Exchange Membrane Fuel Cell

PTC Parabolic Trough solar Collector

PV Photovoltaic

$\mathrm{PV}_{\mathrm{PS}} \quad \mathrm{PV} / \mathrm{CCH} / \mathrm{RO}$ polygeneration scenario

PVT Photovoltaic/Thermal

$\mathrm{Q}_{\text {absorbed }} \quad$ Absorbed solar energy, W/m²

$\mathrm{Q}_{\text {hl_HTF }} \quad$ Heat transfer fluid heat loss, W/m $\mathrm{m}^{2}$

$\mathrm{Q}_{\mathrm{hl}}$ piping $\quad$ Heat lost from solar field pipes, $\mathrm{W} / \mathrm{m}^{2}$

$\mathrm{Q}_{\text {LFR }} \quad$ Solar field useful thermal output, $W / \mathrm{m}^{2}$

$\mathrm{Q}_{\text {in }} \quad$ Incident thermal power, $\mathrm{W} / \mathrm{m}^{2}$

$\mathrm{Q}_{\text {sol }} \quad$ Hourly LF solar thermal energy that is used to supply the $\left(\mathrm{Q}_{\text {need }}(\mathrm{t})\right)$

$\mathrm{Q}_{\text {need }}(\mathrm{t}) \quad$ Hourly required thermal energy of the system

$\mathrm{RO} \quad$ Reverse Osmosis

SAM System Advisor Model

SORC Solar Organic Rankine cycle

SRC Solar Rankine cycle

SWRO Seawater Reverse Osmosis

WP Annual water production, $\mathrm{m}^{3} / \mathrm{yr}$

$\mathrm{T}_{\mathrm{in}, \mathrm{Cool}, \mathrm{w}} \quad$ Temperature of the input stream from the sea

$\mathrm{T}_{\text {out,Cool, } \mathrm{w}} \quad$ Temperature of the output stream to the sea

TES Thermal energy storage

TVC Thermal Vapor Compression

Greek symbols

$\mathrm{a}_{\mathrm{S}} \quad$ Sun elevation angle, degree

$\alpha_{\mathrm{TP}} \quad$ Power temperature coefficient

$\varepsilon \quad$ Effectiveness of heat exchanger

$\eta_{\text {endloss }} \quad$ End loss efficiency

$\eta_{\text {opt }} \quad$ Optical efficiency

$\eta_{\mathrm{PV}} \quad$ PV module efficiency

$\theta_{\mathrm{i}} \quad$ The angle of incidence, degree

$\theta_{\mathrm{z}} \quad$ Zenith angle, degree

$\gamma_{\mathrm{s}} \quad$ Azimuth angle, degree

$\gamma \quad$ PV maximum power temperature coefficient

$\phi_{\mathrm{L}} \quad$ Longitudinal angle, degree

$\phi_{\mathrm{T}} \quad$ Transversal angle, angle 


\section{Appendix A}

The main equations are included two parts; (1) the unit costs of the product associated with the solar thermal (LF) or electricity component (PV) costs (subscripts "solar"), and (2) the unit costs of the products associated with the NGB and fuel prices (subscripts "fuel") or the purchased electricity from the grid. The unit cost of the products includes the direct (DC) or indirect (ID) capital costs (CAPEX) of the component, the insurance cost ( $\mathrm{C}_{\text {Ins }}$ ), labor $\operatorname{cost}\left(\mathrm{C}_{\mathrm{L}}\right)$, spare part replacement costs $\left(\mathrm{C}_{\mathrm{SP}}\right)$ and the electricity cost $\left(\mathrm{C}_{\mathrm{el}}\right)$ for the desalination plants.

Table A1. The cost formulations that were used in the economic analysis of scenario\#1, LFPS.

\begin{tabular}{|c|c|}
\hline \multicolumn{2}{|l|}{ LCH: } \\
\hline $\mathrm{LCH}_{\mathrm{S \# 1}}=\mathrm{LCH}_{\text {solar, S\#1 }} \times(\mathrm{SF})+\mathrm{LCH}_{\text {fuel, S\#1 }} \times(1-\mathrm{SF}) \quad\left(\frac{\$}{\mathrm{kWh} t}\right)$ & (1a) \\
\hline $\mathrm{LCH}_{\text {Solar }, \mathrm{S} \# 1}=\frac{\left[\mathrm{C}_{\mathrm{CAPEX}}(\mathrm{D})+\mathrm{C}_{\mathrm{CAPEX}}(\mathrm{ID})+\mathrm{C}_{\mathrm{Ins}}+\mathrm{C}_{\mathrm{L}}+\mathrm{C}_{\mathrm{SP}}+\mathrm{C}_{\mathrm{el}}\right]_{\mathrm{LF}}}{\mathrm{HP} \times(\mathrm{SF})} \quad\left(\frac{\$}{\mathrm{kWh}}\right)$ & $(2 a)$ \\
\hline $\mathrm{LCH}_{\mathrm{fuel}, \mathrm{S} \# 1}=\frac{\left[\mathrm{C}_{\mathrm{CAPEX}}(\mathrm{D})\right]_{\mathrm{NGB}, \mathrm{S}+1}+\mathrm{C}_{\mathrm{f}}}{\mathrm{HP} \times(1-\mathrm{SF})}$ & (3a) \\
\hline \multicolumn{2}{|l|}{ LCC: } \\
\hline $\mathrm{LCC}_{\mathrm{S \# 1}}=\mathrm{LCC}_{\text {solar, S\#1 }} \times(\mathrm{SF})+\mathrm{LCC}_{\text {fuel, S\#1 }} \times(1-\mathrm{SF}) \quad\left(\frac{\$}{\mathrm{kWh}_{\mathrm{t}}}\right)$ & $(4 a)$ \\
\hline $\mathrm{LCC}_{\text {solar,S\#1 }}=\frac{\left[\mathrm{C}_{\mathrm{CAPEX}}(\mathrm{D})+\mathrm{C}_{\mathrm{CAPEX}}(\mathrm{ID})\right]_{\mathrm{ACH}}}{\mathrm{CP} \times(\mathrm{SF})}+\frac{\mathrm{LCH}_{\mathrm{solar}, \$ \# 1}}{\mathrm{COP}_{A C H}} \quad\left(\frac{\$}{\mathrm{kWh}}\right)$ & $(5 a)$ \\
\hline $\mathrm{LCC}_{\text {fuel, }, \mathrm{SH1}}=\frac{\left[\mathrm{C}_{\mathrm{CAPEX}}(\mathrm{D})+\mathrm{C}_{\mathrm{CAPEX}}(\mathrm{ID})\right]_{\mathrm{ACH}}}{\mathrm{CP} \times(1-\mathrm{SF})}+\frac{\mathrm{LCH}_{\mathrm{fuel}, S H 1}}{\mathrm{COP}_{A C H}} \quad\left(\frac{\$}{\mathrm{kWh}}\right)$ & $(6 a)$ \\
\hline \multicolumn{2}{|l|}{ LCE: } \\
\hline $\mathrm{LCE}_{\mathrm{S \# 1}}=\mathrm{LCE}_{\text {solar, S\#1 }} \times(\mathrm{SF})+\mathrm{LCE}_{\text {fuel, } \mathrm{S \# 1}} \times(1-\mathrm{SF}) \quad\left(\frac{\$}{\mathrm{kWh}}\right)$ & $(7 a)$ \\
\hline $\mathrm{LCE}_{\text {solar, } \mathrm{SH1}}=\frac{\left[\mathrm{C}_{\mathrm{CAPEX}}(\mathrm{D})+\mathrm{C}_{\mathrm{OPEX}}\right]_{\mathrm{ORC}}}{\mathrm{EG} \times(\mathrm{SF})}+\frac{\mathrm{LCH}_{\text {solar, }, \# 1}}{\eta_{\text {ORC }}} \quad\left(\frac{\$}{\mathrm{kWh}}\right)$ & (8a) \\
\hline $\mathrm{LCE}_{\text {fuel, } \mathrm{S} \# 1}=\frac{\left[\mathrm{C}_{\mathrm{CAPEX}}(\mathrm{D})+\mathrm{C}_{\mathrm{OPEX}}\right]_{\mathrm{ORC}}}{\mathrm{EG} \times(1-\mathrm{SF})}+\frac{\mathrm{LCH}_{\text {fuel,SH1 }}}{\eta_{\text {ORC }}} \quad\left(\frac{\$}{\mathrm{kWh}}\right)$ & $(9 a)$ \\
\hline \multicolumn{2}{|l|}{ LCW: } \\
\hline $\mathrm{LCW}_{\mathrm{SH1}}=\mathrm{LCW}_{\text {solar, S\#1 }} \times(\mathrm{SF})+\mathrm{LCW}_{\text {fuel, S\#1 }} \times(1-\mathrm{SF})$ & $(10 a)$ \\
\hline $\mathrm{LCW}_{\text {solar, } \mathrm{SH1}}=\frac{\left[\mathrm{C}_{\mathrm{CAPEX}}(\mathrm{D})+\mathrm{C}_{\mathrm{CAPEX}}(\mathrm{ID})+\mathrm{C}_{\mathrm{Ins}}+\mathrm{C}_{\mathrm{L}}+\mathrm{C}_{\mathrm{SP}}+\mathrm{C}_{\mathrm{el}}\right]_{\mathrm{MED}}}{\mathrm{WP} \times(\mathrm{SF})}+1.55\left[\frac{\mathrm{kWh}}{\mathrm{m}^{3}}\right] \times \mathrm{LCE}_{\mathrm{solar}, \mathrm{SH} 1}+$ & (11a) \\
\hline $\begin{array}{l}Q_{S H_{M E D}} \times \mathrm{LCH}_{\text {solar,SH1 }}\left(\frac{\$}{\mathrm{~m}^{3}}\right) \\
{\left[\mathrm{C}_{\mathrm{CAPEx}}(\mathrm{D})+\mathrm{C}_{\mathrm{CAPF}}(\mathrm{ID})+\mathrm{C}_{\mathrm{Ins}}+\mathrm{C}_{\mathrm{I}}+\mathrm{C}_{\mathrm{SP}}+\mathrm{C}_{\mathrm{e}}\right]}\end{array}$ & (110) \\
\hline $\mathrm{LCW}_{\text {fuel, } \mathrm{SH1}}=\frac{\left[\mathrm{C}_{\mathrm{CAPEX}}(\mathrm{D})+\mathrm{C}_{\mathrm{CAPEX}}(\mathrm{ID})+\mathrm{C}_{\text {Ins }}+\mathrm{C}_{\mathrm{L}}+\mathrm{C}_{\mathrm{SP}}+\mathrm{C}_{\mathrm{el}}\right]_{\mathrm{MED}}}{\mathrm{WP} \times(1-\mathrm{SF})}+1.55\left[\frac{\mathrm{kWh}}{\mathrm{m}^{3}}\right] \times \mathrm{LCE}_{\mathrm{Solar}, \mathrm{S \# 1}}+$ & (12a) \\
\hline$Q_{S H_{M E D}} \times \mathrm{LCH}_{\text {solar,S\#1 }} \quad\left(\frac{\$}{\mathrm{~m}^{3}}\right)$ & (12a) \\
\hline
\end{tabular}

Table A2. The cost formulations that were used in the economic analysis of scenario\#2, $P V_{P S}$.

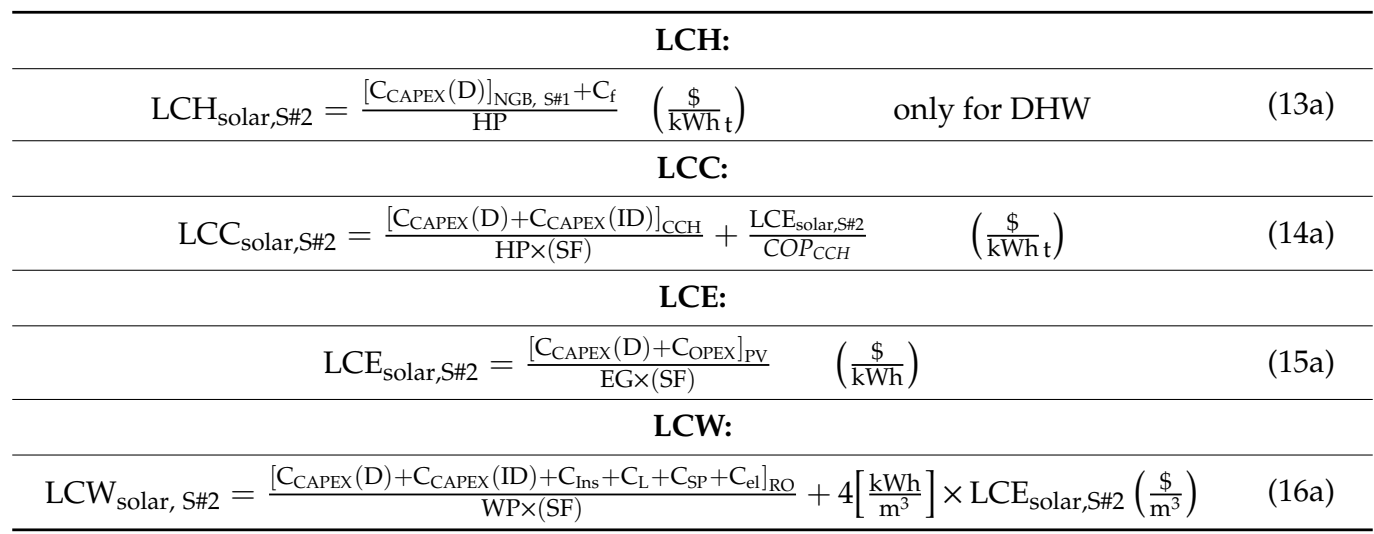


Table A3. Different cost parameters used in economic calculations $[36,37,40,61,62]$.

\begin{tabular}{|c|c|}
\hline \multicolumn{2}{|l|}{ MED Direct Costs (DC), Indirect Costs (IC) and (O\&M) } \\
\hline Main investment $\left(\$ / \mathrm{m}^{3} /\right.$ day $)$ & 1240 \\
\hline Post-treatment plant $\left(\$ / \mathrm{m}^{3}\right)$ & 120 \\
\hline Open sea water intakes $\left(\$ / \mathrm{m}^{3}\right)$ & 313 \\
\hline Drinking water storage and pumping $\left(\$ / \mathrm{m}^{3}\right)$ & 100 \\
\hline Freight \& insurance rate during construction & $5.00 \% \mathrm{DC}$ \\
\hline Owner's cost rate & $10.00 \%$ of direct material and labor cost \\
\hline Contingency rate & $10.00 \%$ of DC \\
\hline Construction overhead (interest during construction) & $12.24 \%$ of DC \\
\hline Electricity costs $\left(\$ / \mathrm{m}^{3}\right)$ & Depending on Electricity cost (Assuming: $1.55 \mathrm{kWh} / \mathrm{m}^{3}$ ) \\
\hline Spare parts Replacement & $1.5 \%$ of total DC \\
\hline Chemical cost of product water $\left(\$ / \mathrm{m}^{3}\right)$ & 0.04 \\
\hline insurance & $0.5 \%$ of total DC \\
\hline Natural Gas auxiliary boiler costs $\left(\$ / \mathrm{m}^{3}\right)$ & 0.02 to 0.8 \\
\hline Labor cost of product water $\left(\$ / \mathrm{m}^{3}\right)$ & 0.025 \\
\hline \multicolumn{2}{|l|}{ RO Direct Costs (DC), Indirect Costs (IC) and (O\&M) } \\
\hline Main investment $\left(\$ / \mathrm{m}^{3} /\right.$ day $)$ & 900 \\
\hline Pretreatment plant $\left(\$ / \mathrm{m}^{3}\right)$ & 250 \\
\hline Post-treatment plant $\left(\$ / \mathrm{m}^{3}\right)$ & 120 \\
\hline Open sea water intakes $\left(\$ / \mathrm{m}^{3}\right)$ & 313 \\
\hline Drinking water storage and pumping $\left(\$ / \mathrm{m}^{3}\right)$ & 100 \\
\hline Wastewater collection \& treatment $\left(\$ / \mathrm{m}^{3}\right)$ & 50 \\
\hline Freight \& insurance rate during construction & $5.00 \% \mathrm{DC}$ \\
\hline Owner's cost rate & $10.00 \%$ of direct material and labor cost \\
\hline Contingency rate & $10.00 \%$ of DC \\
\hline Construction overhead (interest during construction) & $12.24 \%$ of DC \\
\hline Electricity costs $\left(\$ / \mathrm{m}^{3}\right)$ & Depending on Electricity cost (Assuming: $3.5 \mathrm{kWh} / \mathrm{m}^{3}$ ) \\
\hline Spare parts Replacement & $1.5 \%$ of total DC \\
\hline Chemical cost of product water $\left(\$ / \mathrm{m}^{3}\right)$ & 0.04 \\
\hline insurance & $0.5 \%$ of total DC \\
\hline Natural Gas auxiliary boiler costs $\left(\$ / \mathrm{m}^{3}\right)$ & 0.02 to 0.8 \\
\hline Labor cost of product water $\left(\$ / \mathrm{m}^{3}\right)$ & 0.05 \\
\hline \multicolumn{2}{|l|}{ Solar LF Direct Costs (DC) and Indirect Costs (ID) } \\
\hline Site improvement $\left(\$ / \mathrm{m}^{2}\right)$ & 20 \\
\hline Solar filed $\left(\$ / \mathrm{m}^{2}\right)$ & 150 \\
\hline HTF system $\left(\$ / \mathrm{m}^{2}\right)$ & 35 \\
\hline Contingency rate & $7.00 \%$ total DC \\
\hline Design and Construction & $15 \%$ of total DC \\
\hline Land cost $\left(\$ / \mathrm{m}^{2}\right)$ & 10 \\
\hline insurance & $1 \%$ of total DC \\
\hline \multicolumn{2}{|l|}{ ORC Direct Costs (DC) and Operation (OC) } \\
\hline Direct Costs (DC) & $3500 \times \mathrm{P}_{\mathrm{ORC}}[64]$ \\
\hline Operation Costs (OC) $(\$ / \mathrm{kWh})$ & 0.013 \\
\hline \multicolumn{2}{|l|}{ PV Direct Costs (DC) and Operation (OC) } \\
\hline Direct Costs $(\$ / \mathrm{kW})$ & $3300[65]$ \\
\hline Operation Costs (OC) (\$/kW-year) & 25 \\
\hline \multicolumn{2}{|l|}{ ACH Direct Costs (DC) and Operation (OC) } \\
\hline Direct Costs $(\$ / \mathrm{kW})$ & $362[23]$ and [24] \\
\hline Operation Costs (OC) $(\$ / \mathrm{kWh})$ & $15 \%$ of total DC \\
\hline \multicolumn{2}{|l|}{ CCH Direct Costs (DC) and Operation (OC) } \\
\hline Direct Costs $(\$ / \mathrm{kW})$ & $350[24]$ \\
\hline Operation Costs $(\mathrm{OC})(\$ / \mathrm{kWh})$ & $15 \%$ of total DC \\
\hline \multicolumn{2}{|l|}{ NGB Direct Costs (DC) and Operation (OC) } \\
\hline NGB $\left(\$ / k W h t_{\text {nom }}\right)$ & 10 [31] \\
\hline Operation Costs (OC) $(\$ / \mathrm{kWh})$ & 0.0028 \\
\hline
\end{tabular}




\section{References}

1. IRENA. Renewable Power Generation Costs in 2014. 2015. Available online: https://www.irena.org/ documentdownloads/publications/irena_re_power_costs_2014_report.pdf (accessed on 27 August 2019).

2. Technology Road Map: Solar Thermal Electricity-2014 Edition, in, International Energy Agency (IEA) Report. 2014. Available online: http://www.solarconcentra.org/wp-content/uploads/2017/06/Technology-RoadmapSolar-Thermal-Electricity-2014-edition-IEA-1.pdf (accessed on 17 September 2019).

3. Technology Road Map: Solar Photovoltaic Energy-2014 Edition, in, International Energy Agency (IEA) Report. 2014. Available online: https://www.iea.org/publications/freepublications/publication/ TechnologyRoadmapSolarPhotovoltaicEnergy_2014edition.pdf (accessed on 14 November 2019).

4. Observatoire des Energies Renouvelables (ObservER). Worldwide Electricity Production from Renewable Energy Sources. Stats and Figures Series. Thirteenth Inventory. Available online: http://www.energiesrenouvelables.org/observ-er/html/inventaire/Eng/organisation.asp (accessed on 25 September 2019).

5. IEA Report. 2016. Available online: http://energyatlas.iea.org/\#!/tellmap/1378539487 (accessed on 8 September 2019).

6. Baniasad Askari, I.; Oukati Sadegh, M.; Ameri, M. Energy Management and Economics of a Trigeneration System: Considering the Effect of Solar PV, Solar collector and Fuel Price. Energy Sustain. Dev. 2015, 26, 43-55. [CrossRef]

7. Connolly, D.; Lund, H.; Mathiesen, B.V. Smart Energy Europe: The technical and economic impact of one potential 100\% renewable energy scenario for the European Union. Renew. Sustain. Energy Rev. 2016, 60, 1634-1653. [CrossRef]

8. Calise, F.; Dentice d'Accadia, M.; Libertini, L.; Quiriti, E.; Vicidomini, M. A novel tool for thermoeconomic analysis and optimization of trigeneration systems a case study for a hospital building in Italy. Energy 2017, 126, 64-87. [CrossRef]

9. Mancarella, P. MES (multi-energy systems): An overview of concepts and evaluation models. Energy 2014, 65, 1-17. [CrossRef]

10. Kasaeiana, A.; Nouri, G.; Ranjbaran, P.; Wen, D. Solar collectors and photovoltaics as combined heat and power systems: A critical review. Energy Convers. Manag. 2018, 156, 688-705. [CrossRef]

11. Buonomano, A.; Calise, F.; Palombo, A.; Vicidomini, M. Adsorption chiller operation by recovering low-temperature heat from building integrated photovoltaic thermal collectors: Modelling and simulation. Energy Convers. Manag. 2017, 149, 1019-1036. [CrossRef]

12. Desai, N.B.; Bandyopadhyay, S. Thermo-economic analysis and selection of working fluid for solar organic Rankine cycle. Appl. Therm. Eng. 2016, 95, 471-481. [CrossRef]

13. Calise, F.; Dentice d'Accadia, M.; Palombo, A. Exergetic and exergoeconomic analysis of a renewable polygeneration system and viability study for small isolated communities. Energy 2015, 92, $290-307$. [CrossRef]

14. Calise, F.; Dentice d'Accadia, M.; Macaluso, A.; Palombo, A.; Vanoli, L. Exergetic and exergoeconomic analysis of a novel hybrid solar-geothermal polygeneration system producing energy and water. Energy Convers. Manag. 2016, 115, 200-220. [CrossRef]

15. Tzivanidis, C.; Bellos, E.; Antonopoulos, K.A. Energetic and financial investigation of a stand-alone solar-thermal Organic Rankine Cycle power plant. Energy Convers. Manag. 2016, 126, 421-433. [CrossRef]

16. Calise, F.; Dentice d'Accadia, M.; Vicidomini, M.; Scarpellino, M. Design and simulation of a prototype of a small-scale solar CHP system based on evacuated flat-plate solar collectors and Organic Rankine Cycle. Energy Convers. Manag. 2015, 90, 347-363. [CrossRef]

17. Bellos, B.; Tzivanidis, C. Parametric analysis and optimization of an Organic Rankine Cycle with nano fluid based solar parabolic trough collectors. Renew. Energy 2017, 114, 1376-1393. [CrossRef]

18. Bellos, B.; Tzivanidis, C. Investigation of a hybrid ORC driven by waste heat and solar energy. Energy Convers. Manag. 2018, 156, 427-439. [CrossRef]

19. Garcia-Saez, I.; Méndez, J.; Ortiz, C.; Loncar, D.; Becerra, J.A.; Chacartegui, R. Energy and economic assessment of solar Organic Rankine Cycle for combined heat and power generation in residential applications. Renew. Energy 2019, 140, 461-476. [CrossRef]

20. Mazloumi, M.; Naghashzadegan, M.; Javaherdeh, K. Simulation of solar lithium bromide-water absorption cooling system with parabolic trough collector. Energy Convers. Manag. 2008, 49, 2820-2832. [CrossRef] 
21. Chahartaghi, M.; Golmohammadi, H.; Faghih Shojaei, A. Performance analysis and optimization of new double effect lithium bromide-water absorption chiller with series and parallel flows. Int. J. Refrig. 2019, 97, 73-87. [CrossRef]

22. Delač, B.; Pavković, B.; Lenić, K. Design, Monitoring and dynamic model development of a solar heating and cooling system. Appl. Therm. Eng. 2018, 142, 489-501. [CrossRef]

23. Bellos, B.; Tzivanidis, C. Energetic and financial analysis of solar cooling systems with single effect absorption chiller in various climates. Appl. Therm. Eng. 2017, 126, 809-821. [CrossRef]

24. Calise, F.; Dentice d'Accadia, M.; Libertini, L.; Quiriti, E.; Vanoli, R.; Vicidomini, M. Optimal operating strategies of combined cooling, heating and power systems: A case study for an engine manufacturing facility. Energy Convers. Manag. 2017, 149, 1066-1084. [CrossRef]

25. Shirazi, A.; Taylor, R.A.; Morrisona, G.L.; White, S.D. Solar-powered absorption chillers: A comprehensive and critical review. Energy Convers. Manag. 2018, 171, 59-81. [CrossRef]

26. Buonomano, A.; Calise, F.; Palombo, A. Solar heating and cooling systems by absorption and adsorption chillers driven by stationary and concentrating photovoltaic/thermal solar collectors: Modelling and simulation. Renew. Sustain. Energy Rev. 2018, 82, 1874-1908. [CrossRef]

27. Bellos, B.; Tzivanidis, C. Parametric analysis and optimization of a solar driven trigeneration system based on ORC and absorption heat pump. J. Clean. Prod. 2017, 161, 493-509. [CrossRef]

28. Xu, Z.Y.; Wang, R.Z. Comparison of CPC driven solar absorption cooling systems with single, double and variable effect absorption chillers. Sol. Energy 2017, 158, 511-519. [CrossRef]

29. Akrami, E.; Nemati, A.; Nami, H.; Ranjbar, F. Exergy and exergo economic assessment of hydrogen and cooling production from concentrated PVT equipped with PEM electrolyzer and $\mathrm{LiBr}-\mathrm{H} 2 \mathrm{O}$ absorption chiller. Int. J. Hydrog. Energy 2018, 43, 622-633. [CrossRef]

30. Shekarchiana, M.; Moghavvemib, M.; Motasemi, F.; Mahlia, T.M.I. Energy savings and cost-benefit analysis of using compression and absorption chillers for air conditioners in Iran. Renew. Sustain. Energy Rev. 2011, 15, 1950-1960. [CrossRef]

31. Ghafurian, M.M.; Niazmand, H. New approach for estimating the cooling capacity of the absorption and compression chillers in a trigeneration system. Int. J. Refrig. 2018, 86, 89-106. [CrossRef]

32. Calise, F.; Damian Figaj, R.; Massarotti, N.; Mauro, A.; Vanoli, L. Polygeneration system based on PEMFC, CPVT and electrolyzer: Dynamic simulation and energetic and economic analysis. Appl. Energy 2017, 192, 530-542. [CrossRef]

33. Leiva-Illanes, R.; Escobar, R.; Cardemil, J.M.; Alarcón-Padillad, D.C. Thermo economic assessment of a solar polygeneration plant for electricity, water, cooling and heating in high direct normal irradiation conditions. Energy Convers. Manag. 2017, 151, 538-552. [CrossRef]

34. Baneshi, M.; Hadianfard, F. Techno-economic feasibility of hybrid diesel/PV/wind/battery electricity generation systems for non-residential large electricity consumers under southern Iran climate conditions. Energy Convers. Manag. 2016, 127, 233-244. [CrossRef]

35. Baniasad Askari, I.; Ameri, M. Combined linear Fresnel solar Rankine cycle with multi-effect desalination (MED) process: Effect of solar DNI level on the electricity and water production costs. Desalin. Water Treat. 2018, 126, 97-115. [CrossRef]

36. Baniasad Askari, I.; Ameri, M.; Calise, F. Energy, exergy and exergo-economic analysis of different water desalination technologies powered by Linear Fresnel solar field. Desalination 2018, 428, 37-67. [CrossRef]

37. Baniasad Askari, I.; Ameri, M. The application of Linear Fresnel and Parabolic Trough solar fields as thermal source to produce electricity and fresh water. Desalination 2017, 415, 90-103. [CrossRef]

38. Bellos, B.; Tzivanidis, C.; Moschos, K.; Antonopoulos, K.A. Energetic and financial evaluation of solar assisted heat pump space heating systems. Energy Convers. Manag. 2016, 120, 306-319. [CrossRef]

39. Baccioli, A.; Antonelli, M.; Desideri, U.; Grossi, A. Thermodynamic and economic analysis of the integration of Organic Rankine Cycle and Multi-Effect Distillation in waste-heat recovery applications. Energy 2018, 161, 456-469. [CrossRef]

40. Baniasad Askari, I.; Ameri, M. Techno Economic Feasibility Analysis of MED/TVC Desalination Unit Powered by Linear Fresnel Solar Field Direct Steam. Desalination 2016, 394, 1-17. [CrossRef]

41. Baniasad Askari, I.; Ameri, M. Solar Rankin Cycle (SRC) Powered by Linear Fresnel Solar Field and Integrated With Combined MED Desalination system. Renew. Energy 2018, 117, 52-70. [CrossRef] 
42. Fichtner (Fichtner GmbH\&Co. KG) and DLR (Deutsches Zentrum für Luft und Raumfahrt e.V.), MENA Regional Water Outlook, Part II, Desalination Using Renewable Energy, Task 1—Desalination Potential. 2011. Available online: http://www.dlr.de/tt/Portaldata/41/Resources/dokumente/institut/system/projects/MENA_ REGIONAL_WATER_OUTLOOK.pdf (accessed on 2 November 2019).

43. Javadpour, A.; Jahanshahi Javaran, E.; Lari, K.; Baniasad Askari, I. Techno-economic analysis of combined gas turbine, MED and RO desalination systems to produce electricity and drinkable water. Desalin. Water Treat. 2019, 159, 232-249. [CrossRef]

44. Patil, V.R.; Biradar, V.I.; Shreyas, R.; Garg, P.; Orosz, M.S.; Thirumalai, N.C. Techno-economic comparison of solar organic Rankine cycle (ORC) and photovoltaic (PV) systems with energy storage. Renew. Energy 2017, 113, 1250-1260. [CrossRef]

45. Awana, A.B.; Zubair, M.; Praveen, R.P.; Bhatti, A.R. Design and comparative analysis of photovoltaic and parabolic trough based CSP plants. Sol. Energy 2019, 183, 551-565. [CrossRef]

46. Desideri, U.; Campana, P.E. Analysis and comparison between a concentrating solar And a photovoltaic power plant. Appl. Energy 2014, 113, 422-433. [CrossRef]

47. System Adviser Model (SAM), Version 2015.6.30. Available online: https://www.nrel.gov/analysis/sam/help/ html-php/index.html?linear_fresnel_system_costs.htm (accessed on 5 October 2019).

48. Kelly, B.; Kearney, D. Parabolic Trough Solar System Piping Model Final Report, National Renewable Energy Laboratory Subcontract Report NREL/SR-550-40165, July 2006. Available online: Availableelectronicallyathttp://www.nrel.gov/csp/troughnet/pdfs/40165.pdf (accessed on 10 October 2019).

49. PTR70 Parabolic Trough Receiver, National Renewable Energy Laboratory, Technical Report No. NREL/TP-550-45633. Available online: https:/www.nrel.gov/docs/fy09osti/45633.pdf (accessed on 5 November 2019).

50. Kouhikamali, R. Thermodynamic analysis of feed water pre-heaters in multiple effect distillation systems. Appl. Therm. Eng. 2013, 50, 1157-1163. [CrossRef]

51. Persian Gulf Seawater Salinity. Available online: http://www7320.nrlssc.navy.mil/global_ncom/glb8_3b/ html/pgulf.html (accessed on 10 November 2019).

52. Persian Gulf seawater salinity. Available online: http://havajanah.ir/?page_id=924 (accessed on 8 November 2019).

53. Calise, F.; Dentice d'Accadia, M.; Piacentino, A. A novel solar trigeneration system integrating PVT (photovoltaic/thermal collectors) and SW (seawater) desalination: Dynamic simulation and economic assessment. Energy 2014, 67, 129-148. [CrossRef]

54. Yu, H.; Gundersen, T.; Feng, X. Process integration of organic Rankine cycle (ORC) and heat pump for low temperature waste heat recovery. Energy 2018, 160, 330-340. [CrossRef]

55. Zheng, X.; Shi, R.; Wang, Y.; You, S.; Zhang, H.; Xia, J.; Wei, S. Mathematical modeling and performance analysis of an integrated solar heating and cooling system driven by parabolic trough collector and double-effect absorption chiller. Energy Build. 2019, 202. [CrossRef]

56. Underwood, C.P. Advances in Ground-Source Heat Pump Systems, 1st ed.; Woodhead: Cambridge, UK, 2016; pp. 387-421.

57. Baniasad Askari, I.; Ameri, M. The Effect of fuel price on economic analysis of hybrid (photovoltaic/diesel/battery) systems in Iran. Energy Sources Part B Econ. Plan. Policy 2011, 11, 357-377. [CrossRef]

58. Baniasad Askari, I.; Oukati Sadegh, M.; Ameri, M. Effect of heat storage and fuel price on energy management and economics of micro CCHP cogeneration systems. J. Mech. Sci. Technol. 2014, 28, 2003-2014. [CrossRef]

59. Baniasad Askari, I.; Ameri, M. Optimal sizing of photovoltaic-battery power systems in a remote region in Kerman, Iran. Proc. Inst. Mech. Eng. Part A J. Power and Energy 2009, 223, 563-570. [CrossRef]

60. Duffie, J.; Beckman, W. Solar Engineering of Thermal Processes, 2nd ed.; ASME: Hoboken, NJ, USA, 2006.

61. Palenzuela, P.; Zaragoza, G.; Alarcon-Padilla, D.C. Characterisation of the coupling of multi-effect distillation plants to concentrating solar power plants. Energy 2015, 82, 986-995. [CrossRef]

62. Loutatidou, S.; Arafat, H.A. Techno-economic analysis of MED and RO desalination powered by low enthalpy geothermal energy. Desalination 2015, 365, 277-292. [CrossRef]

63. Electricity Incentive Policy in Iran. Available online: http://electricity $\% 20$ and $\% 20$ gas $\% 20$ prices/Iran $\%$ 20Solar\%20Brochure.pdf (accessed on 12 November 2019). 
64. Eveloy, V.; Rodgers, P.; Qiu, L. Hybrid gas turbine-organic Rankine cycle for seawater desalination by reverse osmosis in a hydro carbon production facility. Energy Convers. Manag. 2015, 106, 1134-1148. [CrossRef]

65. Khosravi, A.; Syri, S.; Assad, M.E.H.; Malekan, M. Thermodynamic and Economic analysis of a hybrid ocean thermal energy conversion/photovoltaic system with hydrogen-based energy storage system. Energy 2019, 172, 304-319. [CrossRef]

(C) 2019 by the authors. Licensee MDPI, Basel, Switzerland. This article is an open access article distributed under the terms and conditions of the Creative Commons Attribution (CC BY) license (http://creativecommons.org/licenses/by/4.0/). 